\title{
Job Mobility and the Gender Wage Gap in Italy
}

\author{
EMILIA DEL BONO \\ DANIELA VURI
}

CESIFO WORKING PAPER No. 2435

CATEGORY 4: LABOUR MARKETS

OCTOBER 2008

\footnotetext{
An electronic version of the paper may be downloaded

- from the SSRN website: Www.SSRN.com

- from the RePEc website: $\quad$ www.RePEc.org

- from the CESifo website: www.CESifo-group.org/wp
} 


\title{
Job Mobility and the Gender Wage Gap in Italy
}

\begin{abstract}
This paper investigates the way in which job mobility contributes to the emergence of a gender wage gap in the Italian labour market. We show that men experience higher wage growth than women during the first 10 years of their career, and that this difference is particularly large when workers move across firms. This gender mobility penalty is robust to the inclusion of individual, job and firm characteristics, to different ways of accounting for individual unobserved heterogeneity, and is mainly found for voluntary job moves. Exploring the wage growth of job movers, we find that a significant gender wage penalty emerges when workers move to larger firms. This might be explained by the fact that bigger establishments offer jobs more highly valued by women than men or that the relationship between job satisfaction and firm size is less negative for women than men. Using data on job satisfaction, we find evidence for the latter hypothesis as well as some indication that wages and fringe benefits compensate for lower levels of job satisfaction in larger firms, but that this is so only for men.
\end{abstract}

JEL Code: C23, J62, J16, J31, J28.

Keywords: panel data, job mobility, gender gap, wage growth, job satisfaction.

Emilia Del Bono

Institute for Social \& Economic Research (ISER)

University of Essex

Colchester, Essex, UK CO4 3SQ

United Kingdom

edelbono@essex.ac.uk
Daniela Vuri

University of Rome Tor Vergata

Department SEFEMEQ

Via Columbia 2

00133 Rome

Italy

daniela.vuri@uniroma2.it

October 12, 2008

We would like to thank Vincenzo Atella, Mark Bryan, David Card, John Ermisch, Carlos García-Serrano, Alan Manning, Mark Taylor and seminar participants at the Institute for Social \& Economic Research (Essex), ESPE (Verona), EALE (Prague), ISFOL (Rome), MIT (Boston), SOLE (New York), MIUR Workshop (Rome), and at the Workshop on Gender and the Labour Market (Mannheim) for useful comments and suggestions. We acknowledge ISFOL (Rome) for providing the dataset, Emiliano Rustichelli and Debora Radicchia for their excellent support with the data preparation and Francesca Bergamante for suggesting the use of the ISFOL-Plus dataset. Any error is the authors' sole responsibility. 


\section{Introduction}

This paper analyses gender differences in log wage growth in order to find an explanation for the emergence of a gender pay gap in the early careers of Italian men and women. Using administrative earnings records on a large sample of Italian workers employed in the private sector, we show that a sizeable gender pay gap develops in the years following labour market entry, and that throughout this period women experience significantly lower wage growth than men. Following the US literature, which has shown that wage growth in the early years of labour market experience accounts for over two thirds of lifetime wage growth and that over a third of this increase can be attributed to job-to-job wage gains (Topel and Ward 1992), we focus on the role of job mobility and explore the contribution of individual and firm-specific characteristics to the emergence of what we call the "gender mobility penalty".

This study is motivated by the existence of persistent gender pay differences in the Italian labour market. Although estimates vary according to the measure of earnings adopted and the survey analysed, recent evidence indicates that the difference between average male and female hourly earnings of private sector employees was about 16 percentage points in 2002, and that this gap has remained constant since the mid-1990s (Rustichelli 2005). Another consistent finding is that while gender pay differences are relatively modest at a younger age the gap increases rapidly over time (Biagioli 2007, Tronti 2007). The main factors which lie behind the widening of gender pay differences are still poorly understood, however. In particular, little is known about the role of job mobility beside the fact that job-to-job moves have been found to be more rewarding for men than women (Naticchioni and Rustichelli 2003).

There are several ways to analyse gender differences in wages and in wage growth. The most common approach is based on the theory of human capital as developed by Becker (1993) and Mincer (1974). Several papers have shown that differences in the accumulation of working experience is very important in explaining gender differences in wages (Mincer and Polachek 1974, Mincer and Ofek 1982, Light and Ureta, 1995, O’Neill 2003, Polachek 2006), although others have argued that human capital factors account only for a small component of the gender pay gap (Altonji and Blank 1999, Kunze 2005, Blau and Kahn 2006). Another relevant strand of the literature considers the role of job mobility in explaining wage growth in the first years of labour market experience (Topel and Ward 1992, Dustmann and Meghir 2005). However, while some have found significant gender differences in the returns to mobility (Loprest, 1992), others have argued that there is no significant male-female gap in returns once differences in mobility patterns are taken into account (Keith and McWilliams 1997, 1999), and that gender differences in the process of job search is what matters most instead (Crossley et al. 1994, Manning 2003a). More recently, new areas of investigation have been attempted. For example, Mueller and Plug (2006) and Manning and Swaffield (2008) have explored the contribution of gender differences in 
personality traits on the gender pay gap and on gender differences in wage growth, respectively, but find only modest effects of these variables.

Our data are derived from the Italian Social Security Administration (INPS) archives to form a 1:90 random sample of private sector employees. Information on individual employment spells is collected every year, so it is possible to derive continuous labour market histories for each worker over the period between 1985 and 1998. From these records it is possible to gain access to basic information about the individual, her job and firm. Crucially for our purposes, the archives contain an employer identification number, which allows us to separate within- and between-firm job changes.

Our analysis sheds new light on the existence and the evolution of a gender wage gap in the early careers of Italian men and women. In particular, we find that the average female to male wage ratio is as high as $94.8 \%$ at the time of entry into the labour market, but decreases to about $84.9 \%$ after the first ten years of working experience. By this time, real wages are $44.7 \%$ higher for men but only $29.7 \%$ higher for women. We do not find significantly different rates of labour force attachment of men and women in our sample, but we observe significant and almost constant log wage growth differentials. We also find a significant relationship between the observed gender wage growth differential and job mobility, as men and women experience similar rates of within-firm wage growth but significantly different rates of between-firm wage growth.

This gender mobility penalty is shown to be robust to the inclusion of several individual and firm-specific characteristics and to different ways of accounting for individual unobserved heterogeneity. We also find that although there are gender differences in mobility patterns, a gender gap in returns to between-firm mobility persists even after separating different types of job moves. In particular, we find that women experience lower wage growth than men especially when considering voluntary moves, and argue that fertility and marriage are not the main events which trigger these changes. By exploring the contribution of job and firm-specific characteristics to the gap in between-firm log wage growth, we find that women who move to larger firms experience significantly lower wage increases than men.

The final part of our analysis investigates the reason which may lie behind this last result, namely that women's returns to job mobility are lower than men's when moving towards larger establishments. Our hypothesis is that larger establishments might offer jobs with characteristics more highly valued by women than men or alternatively that the relationship between job satisfaction and firm size is less negative for women that for men. We test this hypothesis by looking at gender differences in the relationship between firm size and job satisfaction using self-reported job satisfaction indicators derived from an additional source of data. We find that not only there is a stronger negative correlation between job satisfaction and firm size for men than for women, but also that wages and fringe benefits act as a compensation for lower levels of job satisfaction 
in larger firms only for men.

The paper is organized as follows. Section 2 describes our data and the variables used in the analysis. Section 3 presents a descriptive account of the presence and evolution of a gender wage gap in the early careers of Italian workers, documents the existence of a persistent gender difference in wage growth rates, and shows that the latter is mainly associated with episodes of between-firm job mobility. In section 4 we analyse the existence of a gender wage growth gap controlling for observed and unobservable characteristics of the individuals, and separating different types of job moves. Section 5 focuses on the wage growth of job movers, and the contribution of specific job and firm characteristics to it. As it turns out that a significant part of the gender wage penalty is observed when workers move to a larger firm, section 6 explores the existence of gender differences in the relationship between job satisfaction and firm size and in the role of wages and fringe benefits as a compensation device. Section 7 concludes.

\section{Data description}

Our data are derived from the Italian Social Security Administration (INPS) archives. This dataset covers a 1:90 random sample of all employees working in the private sector in Italy, and consists of about 160,000 person-year observations (and about 29,000 individuals). The data include information on the sex and the age of the worker, the initial and the final date of the employment spell, the total gross earnings accumulated over that period, the total number of days and weeks worked, an indicator for part-time status, and an occupational qualification code. ${ }^{1}$ We also have an employer identifier and a set of variables related to the firm, such as the industry in which it operates, the geographic location, the average number of employees, and the initial and in some cases also the final - year of activity (descriptives statistics of the main variables are reported in Table A1).

To perform our empirical analysis we select a flow sample of entrants in employment. In particular, we select all individuals who enter the panel between the age of 15 and 18 in 1985, between the age of 15 and 19 in 1986, between the age of 15 and 20 in 1987, and so on up to 1998, which is the last year of our analysis. In this way we are able to follow an individual since her first entry into the labor market, and construct her labour market history. We further select only employment spells which follow the first non-seasonal job, where by seasonal job we intend an employment spell which lasts less than 4 weeks, or a spell which lasts between 4 and 17 weeks

\footnotetext{
${ }^{1}$ The dataset offers information on a number of other potentially interesting variables, such as the type of contract and the type of firm bargaining agreement, but these variables are often not available for the entire period analysed here or have not been coded consistently through time so that they cannot be used to carry out a longitudinal analysis. The main drawback of the dataset is that it does not provide information on individual level of education. As explained in what follows, we will use information on age at entry into the labor market to proxy for education.
} 
and occurs during the period between June and September. In so doing, we exclude spells of employment which are compatible with school as part of the employment history of the worker.

We divide the sample into three groups, used to represent different levels of education: (i) individuals who start working between the age of 15 and 18, (ii) those who start working between the age of 19 to 25, and (iii) those whose first employment spell in the data is observed between the age of 26 and 29. In particular, we refer to employees entering the panel between 15 and 18 years and to those entering the panel between 19 and 25 years as having low and high (secondary) education, respectively. Since those who enter the labour market after age 25 are observed for a very short period of time (as they enter the panel quite late by construction) and are very few (about $3.5 \%$ of the sample), we exclude them from our analysis. ${ }^{2}$

Each record in the original dataset corresponds to a single employment spell when this begins and ends within the same calendar year, while spells which span more than one year are divided into different annual records. In order to derive the working histories of our individuals and analyse their wage growth over time we re-organise the data into a person-year longitudinal dataset with only one record of employment per year. This implies that if there is more than one employment spell during the year, only the longest spell is included in the data. As our focus is on early career wage growth, all individuals included in this study must have at least two yearly records. Therefore, our final sample consists of an unbalanced panel of 130,485 individual-year observations, $42.4 \%$ of which pertain to women.

We define potential work experience as the total number of years since the first entry in the panel, and consider only the first 10 years in the worker's career. Tenure is calculated as the number of weeks an individual is observed working for the same employer and then transformed into years. The earning variable used is the real weekly (gross) wage. ${ }^{3}$ This is obtained by dividing the total amount earned during that year or during that employment spell (if within the year) by the number of weeks worked over that period, and deflating it by the Consumer Price Index (base year 1995).

As we have access to firm identifiers we can analyse changes of employers, which represent

\footnotetext{
${ }^{2}$ In order to check whether grouping individuals by their age of entry in the panel is a reasonable approximation of their level of education we use data from the household survey conducted by the Bank of Italy over the period between 1989 and 1998. This dataset provides information on a representative sample of Italian households and collects details of the economic and social status of their components, including the age at which they started working and their educational qualification. Using this data, we calculate that among those entering the labour market between the age of 15 and 18,72.5 per cent had a lower secondary education qualification, about 25 per cent had a high school diploma, while the remaining fraction reported primary or no education. For those entering the labour market between 19 and 25 years the distribution by level of education was as follows: 74 per cent had achieved a high school diploma, 23 per cent had lower secondary education, while the remaining group was equally divided among those who had already completed a degree (1.5 per cent) or had primary or no qualifications (1.5 per cent). Similar groupings were used by Favaro and Magrini (2005), while Bonjour and Pacelli (1998) tested on Swiss data the size and the direction of bias when age is used as a proxy for education and experience and found that using age as a proxy for education leads to a small bias in the estimated coefficients.

${ }^{3}$ This is because daily wages are potentially more affected by measurement error due to the fact that some employers might declare fewer working days in order to comply with minimum wage requirements.
} 
about $15.5 \%$ of all recorded person-year observations. Changes of jobs within the same firm (recorded as a new employment spell) also occur in the data and represent about $9.0 \%$ of all the individual records. However, while in some cases it is possible to see that a change of job within the same firm corresponds to a change in one of the job characteristics, such as the worker's occupational qualification or part-time status, very often we cannot observe any change in these indicators. This means that what we would label a "within firm job change" could be nothing more than the result of complex administrative procedures. For this reason, in what follows we will focus more on job mobility defined as a change of employer rather than a change of job within the same employer.

\section{Early career wage growth}

We are interested in the factors which might explain the emergence of a gender wage gap. We therefore focus on the early stages of a worker's career and follow our subjects for up to 10 years since their first entry in the labour market. Figure 1 presents log wage profiles disaggregated by sex at different levels of potential experience. As predicted by standard human capital models, we find concave-shaped earnings profiles for both men and women. Log wage rates first increase with experience and then level-off, and this happens slightly earlier for women than for men. As for male-female differences, the figure shows the existence of a small gender wage gap at entry of about $6 \log$ points, which increases over time to reach about 20 log points at the end of the period (top-left panel). ${ }^{4}$

We also display the same log wage profiles for low and high education workers separately (respectively top-right panel and bottom-left panel in figure 1). We see a particularly steep log wage profile for individuals with low education. This is mainly explained by the fact that this group of workers includes apprentices, who have very low wages at the beginning of their careers. ${ }^{5}$ Among these workers, the gender wage gap is about $8 \mathrm{log}$ points at the beginning, and this becomes about $23 \log$ points during the first 10 years of labour market experience. By contrast, among highly educated workers the log wage profile is much flatter and the gender wage gap grows more slowly over time, increasing from 12 to about 18 log points over the observed

\footnotetext{
${ }^{4}$ The existence of a small gender wage gap at entry is consistent with that found by Loprest (1992) for the US (11\%) and Dolton and Makepeace (1986) for the UK (7\%). Kunze (2003) has found instead a much higher gender wage differential at entry of about $23 \%$ for Germany, which remains quite constant through the early working career.

${ }^{5}$ Apprenticeship contracts were introduced in Italy in the early 1950 and were intended to provide workers with some form of internal and external job training while the employer enjoyed a substantial rebate on social security contributions. These contracts were mainly used to provide employers with an incentive to hire young and unqualified workers, and in the vast majority of cases did not lead to any formal qualification. Following the Biagi reform of 2003, apprenticeship contracts have been substantially reformed with the aim to emphasise the training element and define more accurately the professional qualifications associated to them (see Brunello and Topo 2005 for more details).
} 
window.

The pattern of log wages seen in figure 1 translates into the log wage growth rates presented in figure 2. Wage growth is here computed as the difference between two consecutive wage observations, irrespective of whether there has been a gap in the labour market experience of the individual. As we can see, wages first increase at a rate of about 8 log points for the first two years and then start to slow down. There is also substantial heterogeneity in wage growth across education groups; low educated workers exhibit substantially higher wage increases earlier in their career and lower growth later on, while the wage growth profile of highly educated workers appears rather more constant over time. The main thing to notice, however, is that wage growth is consistently higher for men than women during the early stages of a worker's career, and this holds for both levels of education.

These patterns might be driven by changes in rates of labour force participation between men and women over time. In particular, it could be that more women than men exit the sample during the period of observation, or that women experience more frequent and longer career interruptions than men. We can check for this, and in the top panel of table 1 we report the percentage of women in the sample by year of potential experience. This percentage is very stable over time, with women accounting for $41-43 \%$ of the entire sample at each year of experience. Amongst the low educated group a similar pattern emerges, while for the highest educated we notice even some increase in the proportion of women in the last few years. The bottom panel of the table shows the distribution of gaps (in years) between consecutive wage observations. ${ }^{6}$ As we can see, long gaps are relatively infrequent, and generally more likely to be observed among men than women (94.1\% of men never experience a gap of more than one year between wage observations against $95.9 \%$ of women). This is true for the overall sample, as well as for the subsamples defined by different levels of education. It would therefore be unlikely that the observed gender differences in log wages and wage growth profiles are the result of different labour force attachment of men and women in our sample.

Our analysis focuses on the contribution of job mobility in the early stages of a worker's career to the emergence of a gender wage growth gap. The data show that male workers change firm more frequently than women during their early career. About $53.0 \%$ of men in our sample move to another employer at some point over the first 10 years on the labour market, for women this is only $47.7 \%$. However, the year-to-year differences in the incidence of job moves are rather small. The average annual incidence of job moves is $16.8 \%$ for men and $13.9 \%$ for women, a difference

\footnotetext{
${ }^{6}$ If we look at between-firm job changes, we observe that about one third of all changes of employer takes place within 1 month (32.9\% for men and $33.7 \%$ for women), while the mean duration of the interruption is about 10.8 months (11.3 months for men and 10.2 months for women). It is not possible for us to know what individuals do when they are not observed in the data, but such short gaps between job observations would lead us to exclude that they become employed in the public sector or go into self-employment. The most likely scenario is that during the period of time it takes them to move towards another employer these young workers are either unemployed or inactive and that no major gender differences emerge in this respect.
} 
of about 2.8 percentage points. Among the low educated the difference is only 2.0 percentage points, and it is 3 percentage points for those with higher education. Among those who move at least once in the observed period, there are no significant gender differences in the frequency of job changes. We calculate that among job movers the average man has worked with 1.7 employers while the average woman has changed firm 1.6 times. The corresponding numbers are 1.9 and 1.8 for low educated, and 1.6 and 1.5 for high educated men and women, respectively.

On the other hand, comparing the wage growth of men and women and distinguishing withinfirm from between-firm wage changes we find some striking gender differences. Table 2 shows that for the sample of all workers the difference in within-firm wage growth between men and women is only about 0.8 percentage points. When we look instead at changes between firms we see that men gain about 5.6 percentage points more than women on average. In particular, it looks as if men who move to a different firm gain (3.6 log points more than those who stay with the same employer), while women lose (1.2 log points less than those who stay with the same employer). In figure 3 we see that this pattern is observed at all levels of experience and that the picture is very similar across different levels of education.

\section{The gender mobility penalty}

The gender mobility penalty we observe is an overall measure of the difference in returns to mobility among men and women. This means that it does not take into account that men and women are significantly different in respect of important individual characteristics, such as differences in occupation or working hours (see table A.1 in appendix). Moreover, it represents an average across different types of mobility - voluntary or involuntary, for example - and may therefore simply be due to the fact that men and women move for different reasons. In this section we analyse these issues further. We first consider what happens to the gender mobility gap when observed as well as unobserved individual characteristics are controlled for. We then try to separate different types of job mobility and explore whether a gender mobility penalty is found for different types of job moves.

\subsection{Gender differences in returns to mobility}

Our measure of wage growth is obtained by taking the difference in log weekly wages at two different points in time, irrespective of the number of years which separate these two observations. This approach has the advantage of allowing us to consider all individuals in our sample, without imposing arbitrary selections based on the continuity of the labour force experience or the duration of the employment interruptions.

Our wage growth equation is estimated on both men and women and takes into account the 
accumulation of labour force experience as well as the incidence and duration of any gap in the early career. ${ }^{7}$ The equation also includes time-invariant variables and current and lagged values of time-variant regressors which are thought to affect the rate of growth of wages as well as their levels. In a general formulation, the equation can be specified as follows:

$$
\Delta w_{i t}=\phi\left(e_{i t}, n_{i t}, g\right)+\beta f_{i}+X_{i t} \theta+X_{i t+g} \vartheta+Z_{i} \eta+\nu_{i t},
$$

where $\Delta w_{i t}$ represents the change in log weekly wages for individual $i$ between time $t$ and time $t+g$, where $g$ is the gap (in years) between wage observations; $f_{i}$ is the female dummy; $X_{i t}$ and $X_{i t+g}$ represent vectors of observable individual and firm specific characteristics at time $t$ and $t+g$, respectively; $Z_{i}$ is a vector of time invariant individual characteristics; and $\nu_{i t}$ is an i.i.d. error term.

In our empirical specification $\phi()$ is seen as a function of general human capital, tenure, and the duration of the gap between two consecutive wage observations. In particular we assume that:

$$
\phi\left(e_{i t}, n_{i t}, g\right)=\alpha_{0}+\alpha_{1} g+\alpha_{2} e_{i t}+\alpha_{3}\left(e_{i t}\right)^{2}+\alpha_{4} n_{i t}+\alpha_{5}\left(n_{i t}\right)^{2},
$$

where $e_{i t}$ is potential experience, i.e. years since the first entry in the labour market, and $n_{i t}$ is the number of years spent with the same employer.

The quadratic specification imposed in equation (2) could be easily relaxed. In particular, Manning and Swaffield (2008) have recently suggested a more flexible way to account for gaps in consecutive wage observations. Their specification uses an adjusted measure of potential experience and allows wage growth to differ according to the level of experience. However, experimenting with that specification did not lead to significant different results in our case (results not shown but available upon request). This is probably due to the limited number of records with long gaps (> than 1 year) between wage observations in our data. As we control for a very large set of individual and firm specific characteristics, we prefer here a more parsimonious specification and we therefore simply regress wage growth on a quadratic term in potential experience and firm tenure, as well as a linear term for the duration of the interruption.

The first estimates of our wage growth regression are shown in table 3. Column (i) reports the gender difference in log wage growth after controlling for differences in experience and observed job and firm characteristics. As we can see, after netting out the effects of these variables the male-female difference in wage growth turns out to be about $1.3 \log$ points for the whole sample

\footnotetext{
${ }^{7}$ Our analysis is conducted using a pooled equation for men and women but running a separate analysis by sex lead us to the same qualitative results as those presented here. Since gender differences in levels of education are very large in our data ( $52.6 \%$ of men have low education against $37.8 \%$ of women), we prefer to present here results from a pooled equation for men and women as this allows us to highlight differences across education groups instead.
} 
and 1 and $1.5 \log$ points for the sample of low and high educated workers, respectively. We also see that wage growth decreases with potential experience and firm tenure, and that this process decelerates rapidly. The coefficient on the number of years between wage observations is positive, to indicate that wage growth is higher the longer the interruption. ${ }^{8}$ Other factors contribute, and in particular wage growth is low for part-time workers and apprentices, and high in larger firms. ${ }^{9,10}$ As we saw in figure 2 highly educated workers observe lower wage growth than lower educated workers. Differences in the initial contract (apprenticeship vs. others) seem to matter little, except for those with high education.

In column (ii) of table 3 we introduce a dummy to indicate whether change of employer has occurred between time $t$ and time $t+g$ and allow for a gender gap in returns to job mobility by means of an interaction between this dummy and the female dummy. That is, we estimate the following specification:

$$
\Delta w_{i t}=\phi\left(e_{i t}, n_{i t}, g\right)+\beta f_{i}+\gamma c_{i t}+\delta f_{i} * c_{i t}+X_{i t} \theta+X_{i t+g} \vartheta+Z_{i} \eta+\nu_{i t}
$$

where $c_{i t}$ is a dummy assuming value 1 if the individual changes employer between $t$ and $t+g$, and $\delta$ represents the coefficient which captures the gender mobility gap.

Two main results emerge when estimating equation (3). First, once job mobility is taken into account residual gender differences in wage growth (for stayers) are substantially smaller, ranging between 0.7 and 1 log points depending on the sample used. Second, while the returns to mobility for men are virtually zero, women are always found to lose when changing employer. Indeed, the size of the gender mobility penalty is substantial as it accounts for between 3.2 and $4.1 \log$ points of wage growth. ${ }^{11}$

Although we define here job mobility as mobility across firms and do not consider job changes within the same firm for the reasons explained in section 2, it is useful to ask whether ignoring within-firm job changes may affect our results. So, in column (iii) of table 3 we add a dummy to indicate a change of job with the same employer, and consider the interaction of this dummy with the female dummy. As we can see in column (iii) for the entire sample, a within-firm change of job is associated with an increase of log wage growth for men (1.4 log points), while women

\footnotetext{
${ }^{8}$ This result will be further investigated below.

${ }^{9}$ Notice that the INPS data do not offer information on hours of work, but only on part-time and full-time status. However, part-time work was relatively uncommon during the years covered by our data, and mainly concentrated among female workers (see table A1). Variation in hours of work for full-time workers is also likely to be limited. According to data from the 1995 European Structure of Earnings Survey the weekly average hours of work were 39.35 (s.d. 2.94) and 39.14 (s.d. 3.13) for full-time men and women, respectively, and did not vary much when including overtime hours.

${ }^{10}$ The data offer only a highly aggregated code for occupational qualification, which basically allows us to distinguish only blue collar workers (the omitted category) from white collars workers and various categories of apprentices. Further disaggregation of this variable and a more in depth analysis of the role of occupational changes is therefore not possible.

${ }^{11}$ The gender mobility penalty is derived by summing up the female coefficient and the female* change of firm coefficient. This way of computing the difference in log wage growth between men and women will hold throughout.
} 
loose 1.8 log points with respect to men when changing job within firm. However, this is so only for highly educated workers, whereas for low educated workers within-firm mobility does not appear to matter. Moreover, introducing indicators for within-firm job changes does not alter our evidence in respect of the between-firm gender mobility penalty and does not significantly affect the gender penalty for stayers. This seems to confirm that, as far as we can see in our data, the most significant aspect of job mobility related to the existence of a gender wage gap is to be found in between-firm job changes. ${ }^{12}$

We next ask whether the same effect can be found when we control for time-invariant unobserved individual characteristics using a fixed-effects estimator. ${ }^{13}$ In this case the female dummy is not identified, but the gender mobility penalty is identified by the fact that the same individual is observed while moving across firms as well as while staying with the same firm. The results are reported in table 4, where column (i) shows estimates of the gender mobility penalty obtained using an OLS estimator (as in table 3), while column (ii) presents those obtained using an individual fixed-effects estimator. It turns out that the gender mobility penalty estimated via individual fixed-effects is always negative and very close to the OLS estimates (the latters computed as the sum of the female coefficient and the female by change of firm coefficient, as mentioned in footnote 11).

These results rely on a comparison between movers and stayers at a certain point in time. As an alternative way to derive an estimate of the gender mobility gap, we introduce a second control group given by individuals who are stayers between time $t$ and time $t+g$ but move to another firm between time $t+g$ and time $t+g+g^{\prime}$. As suggested by Mincer (1986), it might be reasonable to assume that the next period movers share the same unobservable characteristics of the current period movers. This implies that the on-the-job wage growth next period movers experience in the current period is a better proxy of the wage gain current period movers would have received had they not moved than the current stayers' wage growth rate.

The comparison between current movers and future movers is achieved by estimating the following specification:

$$
\begin{array}{r}
\Delta w_{i t}=\phi\left(e_{i t}, n_{i t}, g\right)+\beta f_{i}+\gamma c_{i t}+\delta f_{i} * c_{i t}+\rho c_{i t+g}+\varrho f_{i} * c_{i t+g}+ \\
+X_{i t} \theta+X_{i t+g} \vartheta+Z_{i} \eta+\nu_{i t}
\end{array}
$$

where $c_{i t+g}$ represents a dummy with value 1 if the individual has not changed employer between $t$ and $t+g$ but will move to another firm between $t+g$ and $t+g+g^{\prime}$. According to this

\footnotetext{
${ }^{12}$ By contrast, Cobb-Clark (2001) shows that gender differences in the rate and the returns to within-firm job mobility (promotions) significantly contribute to the emergence of a gender wage gap.

${ }^{13}$ It would be interesting also to distinguish the contribution of individual-specific unobserved heterogeneity and firm-specific unobserved heterogeneity to the existence of the observed gender mobility penalty (Abowd et al., 1999). Unfortunately, the INPS archives sample individuals and not firms, and this implies that we have too few individual observations at the firm level to estimate a model with both individual and firm fixed-effects.
} 
specification, the gain associated to a change of firm is given by the difference between $\widehat{\gamma}$ and $\widehat{\rho}$ for men, and an additional term given by the difference between $\widehat{\delta}$ and $\widehat{\varrho}$ for women.

As we can see in column (iii) of table 4, the wage change of future female movers in the current period is higher than that of the current stayers (coefficient $\widehat{\varrho}$ ). So, if the current wage change of next period movers is a good proxy of the wage change current movers would have experienced had they not moved then women who move to another firm suffer a penalty even larger than the simple comparison with the group of stayers indicates. Indeed, we see that comparing current female movers with current female stayers results in a gender mobility penalty of about $3.3 \log$ points - column (i) - while using future movers as the control group we obtain a gender penalty of about $5.3 \log$ points - last raw of column (iii). This result holds for the entire sample and for the sub-samples of low and high educated workers and, together with the fixed-effects estimates discussed above, it implies that the observed gender differences in the returns to mobility cannot be simply explained by the presence of unobserved individual heterogeneity.

\subsection{Gender differences in mobility patterns}

As mentioned above, the gender mobility penalty we observe can be explained by differences in mobility patterns among men and women rather than being the result of differences in returns to different types of mobility. For example, the evidence in Keith and McWilliams (1997) suggests that women's lower returns to mobility are mainly explained by their higher propensity to quit for family reasons, and that once different causes for a job change are separated no significant gender differences remain. In this section we follow the same argument and try to separate different types of job mobility.

Since our data are derived from an administrative source, we do not have direct information on the reasons which lead to a job move and need to find alternative ways to distinguish different mobility patterns. What we can do is to see whether there are systematic differences in mobility patterns across men and women which could indicate something about the voluntary or involuntary nature of the separation and test whether the gender penalty is sensitive to this distinction. In order to do so we run several checks. First we separate job moves which could be the result of a mass layoff or a firm closure from other types of moves. Then, we look at the length of the interruption between job changes. Finally we consider whether the gender mobility gap is different across the distribution of wage changes.

In Panel A of table 5 we distinguish changes of firms into changes of employer preceded by a firm closure and those where the previous firm survives. The former should represent involuntary moves, while the latter will be a mixture of involuntary and voluntary separations. Our indicator for firm closure is derived from a variable which indicates the date in which a firm closes down. In particular, we consider a change of firm as being determined by a firm closure when the worker 
leaves that firm during the year preceding closure. ${ }^{14}$ Thus defined, firm closures account for about $10 \%$ of all moves across employers, and are observed more frequently for women (12.3\%) than for men $(8.6 \%)$.

As we can see in column (i), it appears that a change of employer due to a firm closure does not lead to a reduction in wage growth, whereas other types of changes of employer carry a penalty. The situation is however very different once we allow for gender differences in the returns to mobility in column (ii). Here we see that changes of employer which cannot be attributed to a firm closure generally have a positive impact on wage growth (the exception is for high educated workers), but that this is so only for men whereas for women the opposite holds true. In other words, we see that the gender mobility penalty is much larger, and always significant, mainly for job moves not caused by a firm closure. All job moves which are more likely to be involuntary, i.e. that appear to be caused by a firm closure, are not usually associated to different returns by gender.

A second piece of evidence is presented in Panel B of table 5, which distinguishes different types of job mobility by analysing the length of the interval between two jobs with different employers. The distinction between voluntary and involuntary moves is not clear-cut in this case, but it is possible to think that changes of employer which occur quickly are more likely to be the result of voluntary or employee-initiated job moves, while those which require more time are more likely to be involuntary or employer-initiated job separations.

We divide the interval of time between different jobs into three segments. The first category represents moves which occur within 1 month, the second represent moves which occur between 2 and 9 months, while the third represents all the other job changes (the omitted category is always represented by those who stay with the same firm). Each of these categories represents about one third of all job moves. Men and women are equally likely to move quickly across jobs (32.9\% of job changes occurs within 1 month for men, while the corresponding percentage for women is $33.7 \%$ ) but men are slightly more likely to experience very long intervals of non-employment after a job separation (39.5\% of job changes takes 9 months or more for men, while this is the case for only $34.5 \%$ of job separations for women).

The results presented in column (i) clearly indicate that very short intervals between jobs could be seen as representative of voluntary job moves as they are usually associated with higher wage growth. Intermediate and long interruptions seem to carry a penalty, but the size of the coefficient indicates that while intermediate periods of non-employment are mainly involuntary (i.e. carry a high wage growth penalty), long interruptions might be a mixture of voluntary as well as involuntary interruptions. Once we allow for different returns by gender (column [ii]),

\footnotetext{
${ }^{14}$ We also define firm closures only for firms with more than 5 employees, as for very small firms the occurrence of a firm closure does not necessarily represent an involuntary job loss. Experimenting with different cut-offs did not lead to different results.
} 
we see that a significant gender mobility penalty emerges. In particular, we see that women lose the same amount with respect to men when the job change occurs within 1 month of the separation from the previous firm (2.0 log points) and between 2 and 9 months (1.9 log points), but the gender mobility penalty is much larger when the interval between jobs is very long $(7.5 \log$ points). Interestingly, once we allow for differential returns by gender we see that long intervals between jobs are now positively related to wage growth for men. Similar results hold for low and high educated individuals.

Finally, as the distribution of between firm log wage growth is different for men and women (the median wage growth for men is $4.4 \log$ points while for women it is only 3.6), we investigate whether the gender mobility gap is the same across the entire distribution of wage growth, or is concentrated in some parts of it. In order to do so, we run quantile regressions of log wage growth distinguishing the effect of job mobility by gender at the $25 t h$, 50th and 75 th percentile of the distribution. The results are very clear-cut. As we would expect, the returns to job mobility are negative and positive at the lower and upper end of the distribution of wage growth, respectively (column [i]). Once we allow for different returns to mobility by gender (column [ii]), we see however that the gender mobility penalty is always higher at the higher percentiles. So, it seems that the largest gender differences are to be found among those who experience significant wage increases. $^{15}$

The evidence in tables 5 and 6 indicates that, although there are significant gender differences in mobility patterns (with women more likely to separate from closing firms and less likely to experience very long interruptions between jobs), distinguishing different types of job moves does not totally explain differences in returns to mobility by gender. Moreover, we find that job moves which are more likely to be involuntary, i.e. those initiated by a plant closure or characterized by an interruption which lasts for several months (specifically for the period between 2 and 9 months) or which results in lower wage increases, are associated with very small and often insignificant differential returns by gender. On the other hand, the gender mobility penalty is larger for job moves which appear to be positively related to wage growth - such as those which do not follow the closure of a firm, which occur within a very short period of time, or which result in the highest wage increases - and are therefore more likely to be voluntary.

Even voluntary job moves might be due to different reasons, and not all are motivated by money. For example, data from the BHPS show that women are more likely to change job for nonpecuniary reasons as compared to men (Manning 2003a), and that they are more geographically constrained in their job search (Manning 2003b). So, it could be that when women move job they do so because of marriage or the birth of a child, or other reasons related to their family commitments. As long as these types of job moves are less likely to be associated with wage

\footnotetext{
${ }^{15}$ Fitzenberger and Kunze (2005) perform a similar analysis for Germany but they look at the gender gap in wage levels. They find that the gender mobility gap is highest in the lower part of the wage distribution.
} 
growth than moves due to career considerations, we might observe a gender mobility gap.

In Italy the situation appears to be quite different, however. Numerous studies show that Italian women are very unlikely to leave their job because of family circumstances and re-enter the labour force at a later date. The typical pattern is one in which women either stay attached to their job or exit employment permanently after marriage or the birth of a child (Bratti et al. 2005, Geyer and Steiner 2007, Pacelli et al. 2007). Data from the 1998 Multiscopo Survey suggest that only $0.5 \%$ of women interrupt their working career temporarily because of the birth of a child, and this percentage is $6.8 \%$ for women aged 25-34. Additional evidence comes from data from the 2004 European Household Survey (Eu-Silc), which show that young women are only slightly more likely than young men to cite the need to look after children (or other family members) or the event of marriage as the most likely reason for a recent change of employer (table 7).

As our data are from an administrative source, it does not offer information on the reason for a change of employer. However, the women in our sample are aged between 15 and 31, with a mean of 22.5 years, and data from the RTFL (Italian Labor Force Survey) suggest that marriage occurs on average between 24 and 26 years while the birth of the first child takes place between 27 and 28 years. We also find that only a small fraction of episodes of maternity leave (about $7 \%$ ) are followed by a change of employer, while changes in the geographical location of the job are more frequent for men than women (19.5\% of all changes of employer imply a change of province for men, while for women this is 12.9\%). ${ }^{16}$ Overall, these figures would seem to suggest that marriage and fertility are unlikely to be the main events preceding the job-to-job transitions we observe in our data. This does not imply, however, that we exclude that marriage and fertility considerations influence the process of job search. It is possible that women choose jobs facilitating the achievement of a work-life balance well in advance of the formation of a family. In this case, the process of search for a new job could be different across men and women, in that the latter could, for example, value more certain characteristics of the new employer and accept a slightly lower wage in exchange. We return to this point below.

\section{$5 \quad$ Wage growth of job movers}

So far we have controlled for job and firm characteristics using a full set of dummies for part-time status, occupation, industry, firm size, firm age, and region at time $t$ and at time $t+g$ in the wage growth equation. We now turn to analyse more specifically the role of these job and firm characteristics. In order to do so we summarise the information by means of dummies indicating whether there has been a change in one of these variables between two points in time. As we

\footnotetext{
${ }^{16}$ Unfortunately, we have information on maternity leave spells only from 1993 onwards and for this reason this variable is not used throughout our analysis.
} 
have shown that a significant part of the gender gap in log wage growth can be attributed to between-firm changes, in this section we focus our analysis on wage growth for those who change employer.

Table 8 presents a set of regressions which show the effect of these changes. In column (i) we report the average gender differential in between-firm wage growth, controlling only for human capital accumulation, the number of years between two different wage observations and a set of year dummies. In table 2 we saw that the raw gender difference in wage growth for firm movers was about $5.6 \log$ points for the entire sample, and 5.1 and $4.6 \log$ points for the subsamples of low and high educated workers, respectively. The results in table 8 suggest that gender differences in human capital and in the incidence and duration of the work interruptions account only for a small fraction of these between-firm gender differences in wage growth. Indeed, the gender mobility penalty remains negative and quite significant and is shown to be between 4.3 and 5.0 log points, depending on the level of education.

In column (ii) we introduce a set of dummies indicating changes of part-time status (distinguishing between changes from part-time to full-time and viceversa), occupation, firm size (distinguishing between changes to larger and smaller firms), firm age category, sector of activity and region of work. As we can see, most of these dummies are significantly correlated to log wage growth. In particular, we see that the dummies representing changes in part-time status exhibit the highest coefficients overall and show an almost symmetrical effect. Other important determinants are represented by changes of occupation and changes of firm size, with moves to larger (smaller) firms being positively (negatively) associated with wage growth. The coefficient on the female dummy decreases, but it remains always significant, to indicate that not all the gender mobility gap can be entirely explained by those changes.

In column (iii) we go a step further and introduce interactions between the dummies representing changes in job or firm characteristics and the female dummy. This is in order to allow for different returns to different types of moves across men and women. As we can see, there is evidence of significant gender differences in returns to mobility when a change of occupation, firm size or region occurs. ${ }^{17}$ In particular, changes to a larger firm are always less beneficial for women than men in terms of wage growth, and this result holds for the entire sample as well as

\footnotetext{
${ }^{17}$ The return to change of occupation is per se an interesting result which would deserve further investigation. Analyses not shown here but available on request from the authors indicate that women experience a wage growth penalty with respect to men when changing from an apprenticeship to either a blue collar or a white collar occupation. This could be explained by the fact that apprenticeship contracts are an institution introduced a long time ago, and mainly targeted at a male-dominated workforce. As we argue in footnote 5, over time these contracts became a way to facilitate young workers' entry into the labour market and their training content was greatly overlooked. It is however possible that insofar as a training element remains this is more valuable for male-dominated occupations than female-dominated occupations and therefore women benefit less than men from entering in the labour market as apprentices. Unfortunately, since we do not have a disaggregated code for occupational qualifications we cannot provide more insights on this result.
} 
for the subsamples of low and high educated workers. ${ }^{18}$ Interestingly, in this specification the coefficient on the female dummy becomes very small and totally insignificant. This suggests that a possible explanation for the gender mobility gap is to be found in the different returns men and women receive when changing occupation, region, and firm size.

As there are several categories for occupation, firm size, firm age, sector of activity and about 17 regions, there are slightly more sophisticated ways to control for changes in these variables and their contribution to the gender mobility gap. Following Loprest (1992) and Winter-Ebmer and Zweimuller (1999), we build a set of variables which represent the average premium (or penalty) associated with a specific change in one of these categorical variables. The premium is obtained as the difference in the coefficients of a regression in levels of log wages on the usual set of human capital variables, part-time status, occupation, firm size, firm age, sector of activity, region and year dummies. The regression in levels is estimated on the whole sample, including periods in which the individual has not changed firm, and it does not include a gender dummy. This regression gives us the cross-sectional coefficients that represent the relationship between average wages and firm and job characteristics.

Using firm size as an example, the OLS estimation of log wages on firm size dummies and all other controls produce the following results:

$$
\ln w_{i t}=\ldots+0.043(\text { size } 5-14)_{i t}+0.103(\text { size } 15-99)_{i t}+0.172(\text { size } 100+)_{i t}+\ldots
$$

where $w_{i t}$ is the gross daily wage rate and firms with less than five employees are the reference category. We then calculate a new variable representing the premium associated with each possible combination of the cross-sectional coefficients obtained. For example, the average increase in log wages obtained when moving from a firm of size 5-14 to a firm of size 15-99 will be computed as:

$$
\Delta \ln w_{i, t \mid[\operatorname{size}(15-99)-\operatorname{size}(5-14)]}=0.103-0.043=0.060 .
$$

So, for each change of employer between time $t$ and $t-1$ we have a single variable which gives us the premium associated to that specific change of firm characteristics. We then run a regression of log wage growth onto the usual set of controls and the variables representing the average premium due to a change of occupation, firm size, firm age, industry and region constructed using the procedure described above. The coefficient on the variable representing the firm-size premium obtained from the log wage growth regression will tell us, for example, how much of the average cross-sectional log wage premium associated to a change of firm size is to be attributed to

\footnotetext{
${ }^{18}$ Women are more likely to move towards a larger firm when changing employer. Among men who change firm we observe that $38.5 \%$ stay in firms of equivalent size, $37.5 \%$ move towards larger firms, and $24.1 \%$ move towards smaller firms. The corresponding percentages are $43.1 \%, 35.2 \%$ and $21.8 \%$ for women.
} 
changes across employers. The interaction between this variable and a gender dummy will reflect whether there are significant gender differences in terms of the premium (or penalty) gained when moving across the same type of firms or jobs.

Table 9 shows the results. ${ }^{19}$ We first present a specification in which we consider only a female dummy and the occupation, firm size, firm age, sector of activity and region average premiums. ${ }^{20}$ As we can see in column (i), individuals changing occupation claim about 92 per cent of the OLS estimated qualification premium. Similarly, individuals who move to larger firms gain about 75 per cent of the firm size premium implied by the cross-sectional estimates, while those who move to smaller firms see their wage decrease by more than 88 per cent of the estimate predicted by OLS. These results do not differ much across subsamples, and in all the regressions shown the female dummy remains statistically significant.

We then consider the interaction between these variables and the female dummy (column [ii]) and see some very interesting results. The female dummy is now insignificant, and this implies that most of the gender mobility gap has now been absorbed by one of the interactions. In particular, while changes in sector of activity, firms with different age, and region do not differ by gender, we observe significant gender differences when changing occupation and in returns to moves towards a larger firm. The latter coefficient is particularly large and is observed for the whole sample as well as for the subsamples of low and high educated workers. This evidence, together with what we saw in table 8 , would seem to suggest that a significant part of the explanation of the gender mobility gap is to be found in the wage growth penalty women experience when moving to larger firms.

\section{Gender, firm size and job satisfaction}

In this section we investigate the previous result, namely that women's returns to job mobility are lower than men's when workers move to larger firms. A possible explanation of this phenomenon is that larger firms offer jobs with characteristics more valued by women than men or - to put it slightly differently - that the relationship between job satisfaction and firm size is less negative for women than for men. If this were the case, and if wages compensate for lower levels of satisfaction, then women moving from a small to a large firm might experience lower wage growth than men.

There is already some evidence in the literature that levels of job satisfaction are lower in large firms compared to small ones (Bender et al. 2005, Asadullah and Fernández 2008). This has been

\footnotetext{
${ }^{19}$ The coefficients on the variables reported in table 9 are to be interpreted as premiums or penalties according to the sign of the corresponding variables shown in table 8. For example, the coefficient on sector shown in column (i) of table 9 (0.868) should be interpreted as a penalty since the coefficient on change of sector in column (i) of table 8 is negative $(-0.015)$.

${ }^{20} \mathrm{We}$ also control for dummies for changes in part-time status, for general and firm specific experience, a linear term in the years of interruption between jobs and time dummies (not shown).
} 
explained by the fact that large firms implement a more rigid organization of work and offer jobs with a lower degree of autonomy with respect to small firms (Idson 1990, García-Serrano 2008). However, to the best of our knowledge, very little is known about the extent of gender differences in the relationship between job satisfaction and firm size, and so far there is no evidence that wages compensate for the lower levels of job satisfaction observed in large firms (Winter-Ebmer and Zweimueller 1999, García-Serrano 2008).

In this section we try to shed some light on these two aspects. In particular, we look at the relationship between several indicators of job satisfaction and firm size, and consider the role of wages as a compensating device. Under the hypothesis that wages are utility-equalizing, we should observe insignificant (or small) differences in levels of job satisfaction according to firm size. Conditional on the individual wage, however, we should observe a negative (or more negative) relationship between job satisfaction and firm size (Winter-Ebmer and Zweimuller 1999).

In order to perform this analysis we use data from the 2005 ISFOL-Plus survey. ${ }^{21}$ This survey collects information on a nationally representative sample of more than 40,000 individuals aged 15-65 and asks questions about economic activity, earnings, hours of work, and - crucially for our purposes - firm size and several aspects of job satisfaction. From this data we select a sample of employees aged 35 years or younger, currently working in the private sector, and analyse the relationship between several indicators of job satisfaction, gender, and firm size after controlling for a set of standard individual and job characteristics, aspects of the organization of work (such as the presence of shift work, night and weekend work, and the presence of rigid working hours arrangements), and the general economic conditions of the firm (whether a merger or acquisition has occurred or the firm has been hiring in the past year). For each indicator of job satisfaction we look at the relationship between job satisfaction and firm size when monetary elements of the compensation (log of hourly wage and various fringe benefits) are excluded or included. Estimation will be performed by means of discrete choice statistical models, such as probit and ordered probit, to reflect the nature of the dependent variables.

As we can see from table 10, we use several indicators of job satisfaction. In particular, we consider here a dummy variable which assumes value 1 when the individual has been looking for a job and zero otherwise (column (i)) and several variables indicating self-reported levels of satisfaction about: (ii) the working environment (relationships with colleagues), (iii) hours of work (hours, overtime, paid holidays, etc.), (iv) the tasks performed, (v) career prospects, (vi) training opportunities, and (vii) job security. The table presents separate results for men (Panel

\footnotetext{
${ }^{21}$ Because of its administrative nature, the INPS dataset offers only indirect indicators of levels of job satisfaction. We performed some analysis on the indicators of job satisfaction which could be derived from this dataset, such as the propensity to move to another job within the next year or the number of weeks of paid sick leave (assumed to be an indicator of absenteeism). The results we obtained are qualitatively similar to those obtained below using more direct measures of job satisfaction available from the ISFOL-Plus survey and are not discussed here for the sake of brevity.
} 
$\mathrm{A}$ and B) and women (Panel C and D). This is in order to keep the interpretation as simple as possible as the calculation of interaction effects in non-linear models such as probit or ordered probit is rather cumbersome, but also because what we are looking for in this case if evidence of gender differences in the relationship between job satisfaction and firm size rather than gender differences in the levels of job satisfaction according to firm size. ${ }^{22}$ In Panel $\mathrm{A}$ and Panel $\mathrm{C}$ we report the coefficients on the firm-size dummies when no controls for wages or fringe benefits are included, while in Panel B and Panel D we report those obtained after conditioning on these variables.

As we can see, without conditioning on the wage and fringe benefits we find virtually no relationship between firm size and the probability of looking for another job, and this is so for men and women alike. Once we condition on the level of the hourly wage and other forms of monetary compensation ( $\mathrm{p}$-value of the joint test on these variables shown in the last row of each panel) we see however that men in medium-size firms are found to be significantly less likely than men in small firms to engage in job search activities, while the results do not change in the case of women. When we look at levels of satisfaction with the working environment (column (ii)), we find evidence of a negative effect of firm size, and that this relationship becomes stronger after accounting for wages and fringe benefits. For women, there is a less significant negative effect of firm size on levels of satisfaction, and this relationship does not change at all once we include controls for monetary aspects of the compensation. Another striking case is found when looking at differences in satisfaction with career. Here we find a rather strong negative association between satisfaction and firm size for men, especially when controlling for monetary compensation, but absolutely no effects for women. This pattern - namely a less negative relationship between firm size and levels of job satisfaction for women than men and a substantially smaller effect of wages and fringe benefits on the firm-size dummies for women than men - holds throughout and is robust to various specifications.

These results point out two main findings. First, we see that men in larger firms experience significantly lower levels of job satisfaction than men in smaller firms, while for women this difference is less pronounced. This could be explained by the fact that women value aspects of the jobs offered by large firms more than men. Unfortunately, we can only speculate about the nature of these job characteristics, as we do not have much information about firms or the jobs they offer. Notice, however, that we control for the presence of rigid working hours, shift work and night and weekend work, which are all found to be more common in larger firms, and that in Italy it is extremely rare for an employer to offer on-site childcare. It is therefore unlikely that flexible hours and the provision of childcare are among the "job amenities" which would

\footnotetext{
${ }^{22}$ We note however that estimation of pooled equations with interactions between firm size dummies and sex revealed significant coefficients on these interactions for many indicators of job satisfaction, in particular those related to satisfaction with career and job security.
} 
explain our results. Other factors may matter instead, such as easier access to training, or more intra-firm mobility for example. ${ }^{23}$ These "job amenities" are more easily available in larger firms and might be particularly attractive for young women who are in the process of forming a family, as they might guarantee a greater choice of career opportunities and a more satisfactory work-life balance in the future.

Secondly, it appears that wages and fringe benefits partly compensate for lower levels of job satisfaction in larger firms, but that this is so only for men. We can only speculate about why this seems to be the case. One possibility, which has been highlighted by the recent experimental literature on gender differences, is that women are less likely to engage in bargaining than men. For example, in a recent laboratory experiment participants were told they would be paid between $\$ 3$ and $\$ 10$ for their participation. After the experiment finished, the participants were asked "Here is $\$ 3.0$. Is $\$ 3.0$ OK?". Only $2.5 \%$ of the female participants against $23 \%$ of the male participants requested more money (Small et al. 2007). Babcock (2002) reports that among MBAs graduates from Carnegie Mellon only $7 \%$ of women attempted to negotiate their first placement offer, whereas $57 \%$ of men engaged in negotiation. Under the assumption that salary negotiation is more common in larger firms, gender differences in the propensity to bargain over the wage package would be consistent with the results presented in this section and would also explain our previous findings on the gender mobility gap. Another possibility is simply that women are less interested than men in bargaining over wages and fringe benefits because they value more other aspects of the jobs offered by large firms. In other words, it is possible that omitted variables representing job characteristics which are more common in larger firms and that are more valued by women than men could explain both the observed gender difference in the relationship between job satisfaction and firm size as well as the different role of wages and fringe benefits as a measure of compensation.

\section{Conclusions}

This paper represents the first attempt to try to disentangle the factors that might lie behind the existence of a gender wage gap in the Italian labour market by looking at the contribution of early-career job mobility. Using a longitudinal dataset derived from administrative records, we analyse the determinants of gender differences in log wage growth during the first 10 years of labour market experience of a large groups of Italian workers. The empirical evidence is disaggregated by level of education and takes into account the contribution of individual, job and firm-specific characteristics.

\footnotetext{
${ }^{23}$ This interpretation seems particularly consistent with the finding that the most important gender differences in the relationship between job satisfaction and firm size are found when considering levels of satisfaction with career prospect and job security.
} 
Our analysis shows the existence of a modest gender differences in wage levels at entry, and a substantial widening of this gap over time. We also find that while men and women in our sample exhibit a similar pattern of labour force participation, they experience substantially different rates of wage growth and that this gender differential is particularly large when considering betweenfirm, rather than within-firm job changes. This gender mobility penalty is shown to be robust to the inclusion of several individual and firm-specific characteristics, to different ways of accounting for individual unobserved heterogeneity, and in contrast with some of the evidence for the US (Keith and McWilliams 1997) it remains significant even after separating different types of job moves.

Using the information in our data, we consider the contribution of specific changes in job and firm characteristics, and find that a significant part of the gender wage penalty is observed when workers move to a larger firm and that this effect is observed across all subsamples. We think this can be explained by the fact that men and women care about different aspects of their jobs, and in moving to a larger firm women might experience less of a decrease in their levels of job satisfaction as compared to men and therefore require less compensation in terms of higher wages. We test this hypothesis by looking at gender differences in the relationship between firm size and job satisfaction using self-reported data on job satisfaction derived from an additional source of data. Our findings indicate that there is a stronger negative correlation between job satisfaction and firm size for men than for women, and that wages and fringe benefits act as a compensation only for men and not for women. One possible explanation for these results is that women value certain characteristics of the jobs offered by large firms more than men, but also that they might be less likely than men to engage in salary negotiations.

As far as we are aware, these are new results in the literature. They suggest not only an explanation of the gender mobility gap we observe in the early careers of Italian men and women, but point out the importance of analysing gender differences in levels of job satisfaction and in salary negotiations. It would be very interesting to see whether these findings can be replicated using data on other countries, hold for older workers, or remain significant when more controls for working conditions are included. 


\section{References}

Abowd J, Kramarz F, Margolis D. High-Wage Workers and High-Wage Firms, Econometrica $1999 ; 67 ; 251-333$.

Altonji J, Blank R. Race and Gender in the Labor Market. In: Ashenfelter O and Card D (Eds), Handbook of Labor Economics, vol. 3C. North Holland: Amsterdam; 1999; pp. 3143-259.

Asadullah MN, Fernández R. Work-Life Balance Practices and the Gender Gap in Job Satisfaction in the UK: Evidence from Matched Employer-Emploee Data. IZA Discussion Paper 2008 ; n. 3582.

Babcock, L. Do Graduate Students Negotiate their Job Offers? Mimeo, Carnergie Mellon University; 2002.

Becker G. Human Capital: a Theoretical and Empirical Analysis, with Special Reference to Education (3rd edition). University of Chicago Press: Chicago; 1993.

Bender K, Donohue S, Heywood J. Job Satisfaction and Gender Segregation. Oxford Economic Papers 2005; 57; 479-496.

Biagioli, M. I differenziali salariali uomo/donna nell'indagine ISTAT sulla struttura delle retribuzioni. In: Rustichelli E (Ed), Esiste un differenziale retributivo di genere in Italia? Il lavoro femminile tra discriminazioni e parita' di trattamento. I libri del FSE: Roma, ISFOL; 2007; pp. 129-182.

Blau F, Kahn L. The US Gender Pay Gap in the 1990s: Slowing Convergence. Industrial and Labor Relations Review 2006; 60; 45-66.

Bonjour D, Pacelli L. Wage Formation and the Gender Wage Gap: Do Institutions Matter? Italy and Switzerland Compared, U.C.L. Discussion Paper 1998; n. 12.

Bratti M, Del Bono E, Vuri D. New Mothers' Labour Force Participation in Italy: The Role of Job Characteristics. Labour 2005; 19; 79-121.

Brunello G, Topo A. Il nuovo apprendistato professionalizzante: dalla formazione apparente alla formazione effettiva? Rivista Italiana di Diritto del Lavoro 2005; 24; 33-58.

Cobb-Clark D. Getting Ahead: The Determinants of and Payoffs to Internal Promotion for Young Men and Women. Research in Labor Economics 2001; 20; 339-372.

Crossley T, Jones S, Kuhn P. Gender Differences in Displacement Costs: Evidence and Implications. Journal of Human Resources 1994; 29; 461-480.

Dolton P, Makepeace G. Sample Selection and Male Female Earnings Differentials in the Graduate Labour Market. Oxford Economic Papers 1986; 38; 317-341.

Dustmann C, Meghir C. Wages, Experience and Seniority. Review of Economic Studies 2005; $72 ; 77-108$.

Favaro D, Magrini S. Group versus Individual Discrimination among Young Workers: A Distributional Approach. Universita' Ca' Foscari di Venezia; Nota di Lavoro 2005; n. 2.

Fitzenberger B, Kunze A. Vocational Training and Gender: Wages and Occupational Mobility among Young Workers. Oxford Review of Economic Policy 2005; 21; 392-415. 
García-Serrano, C. Does Size Matter? The Influence of Firm Size on Working Conditions and Job Satisfaction. ISER Working Paper; n. 2008-30.

Geyer J, Steiner V. Short-Run and Long-Term Effects of Childbirth on Mothers' Employment and Working Hours Across Institutional Regimes: An Empirical Analysis Based on the European Community Household Panel. IZA Discussion Paper 2007; n. 2693.

Idson T. Establishment Size, Job Satisfaction and the Structure of Work. Applied Economics 1990; 22; 1007-1018.

Keith K, McWilliams A. Job Mobility and Gender-Based Wage Growth Differentials. Economic Enquiry 1997; 35; 320-333.

Keith K, McWilliams A. The Returns to Mobility and Job Search by Gender. Industrial and Labor Relations Review 1999; 52; 460-477.

Kunze A. Gender Differences in Entry Wages and Early Career Wages. Annales d'Economie et Statistique 2003; 71/72; 245-266.

Kunze A. The Evolution of the Gender Wage Gap. Labour Economics 2005; 12; 73-97.

Light A, Ureta M. Early-Career Work Experience and Gender Wage Differentials. Journal of Labor Economics 1995; 13; 121-154.

Loprest P. Gender Differences in Wage Growth and Job Mobility. American Economic Review $1992 ; 82 ; 526-532$.

Manning A. Monopsony in Motion: Imperfect Competition in Labor Markets. Princeton University Press: Princeton; 2003(a).

Manning A. The Real Thin Theory: Monopsony in Modern Labour Markets. Labour Economics 2003(b); 10; 105-131.

Manning A, Swaffield J. The Gender Gap in Early-Career Wage Growth. Economic Journal $2008 ; 118 ; 983-1024$.

Mincer J. Schooling, Experience and Earnings. National Bureau of Economic Research: New York; 1974.

Mincer J. Wage Changes in Job Changes. In: Ehrenberg R (Ed), Research in Labor Economics 1986; vol. 8; pp. 171-197.

Mincer J, Ofek H. Interrupted Work Careers: Depreciation and Restoration of Human Capital. Journal of Human Resources 1982; 17; 3-24.

Mincer J, Polachek S. Family Investments in Human Capital: Earnings of Women. Journal of Political Economy 1974; 82; S76-108.

Mueller G, Plug E. Estimating the Effect of Personality on Male-Female Earnings. Industrial and Labor Relations Review 2006; 60; 3-20.

Naticchioni P, Rustichelli E. The Impact of Job-to-Job Labour Mobility on Wage Dynamics in the Medium-long Run in Italy. Mimeo; 2003.

O’Neill J. The Gender Gap in Wages, Circa 2000. American Economic Review Papers and Proceedings 2003; 93; 309-314. 
Pacelli L, Pasqua S, Villosio C. What Does the Stork Bring to Womens Working Career? LABORatorio Revelli Working Papers Series 2007; n. 58.

Polachek S. How the Human Capital Model Explains Why the Gender Gap Narrowed. In: Blau F, Brinton M, Grusky D (Eds), The Declining Significance of Gender? Russell Sage Fundation: New York; 2006; pp. 102-124.

Rustichelli E. I differenziali retributivi di genere. In: Battistoni L (Ed), I numeri delle donne. "Quaderni Spinn": Roma; 2005; pp. 79-106.

Small, D, Gelfand, M, Babcock, L, Gettman, H. Who Goes to the Bargaining Table? Journal of Personality and Social Psychology 2007; 93; 600-613.

Topel R, Ward M. Job Mobility and the Careers of Young Men. Quarterly Journal of Economics 1992; 107; 439-479.

Tronti, Lionello 2007. Differenziali retributivi: un'analisi dello scenario italiano In: Rustichelli E (Ed), Esiste un differenziale retributivo di genere in Italia? Il lavoro femminile tra discriminazioni e parita' di trattamento. I libri del FSE: Roma, ISFOL; 2007; pp. 113-115.

Winter-Ebmer R, Zweimuller J. Firm-Size Wage Differentials in Switzerland: Evidence from Job-Changers. American Economic Review 1999; 89; 89-93. 
Figure 1: Log wage by potential experience

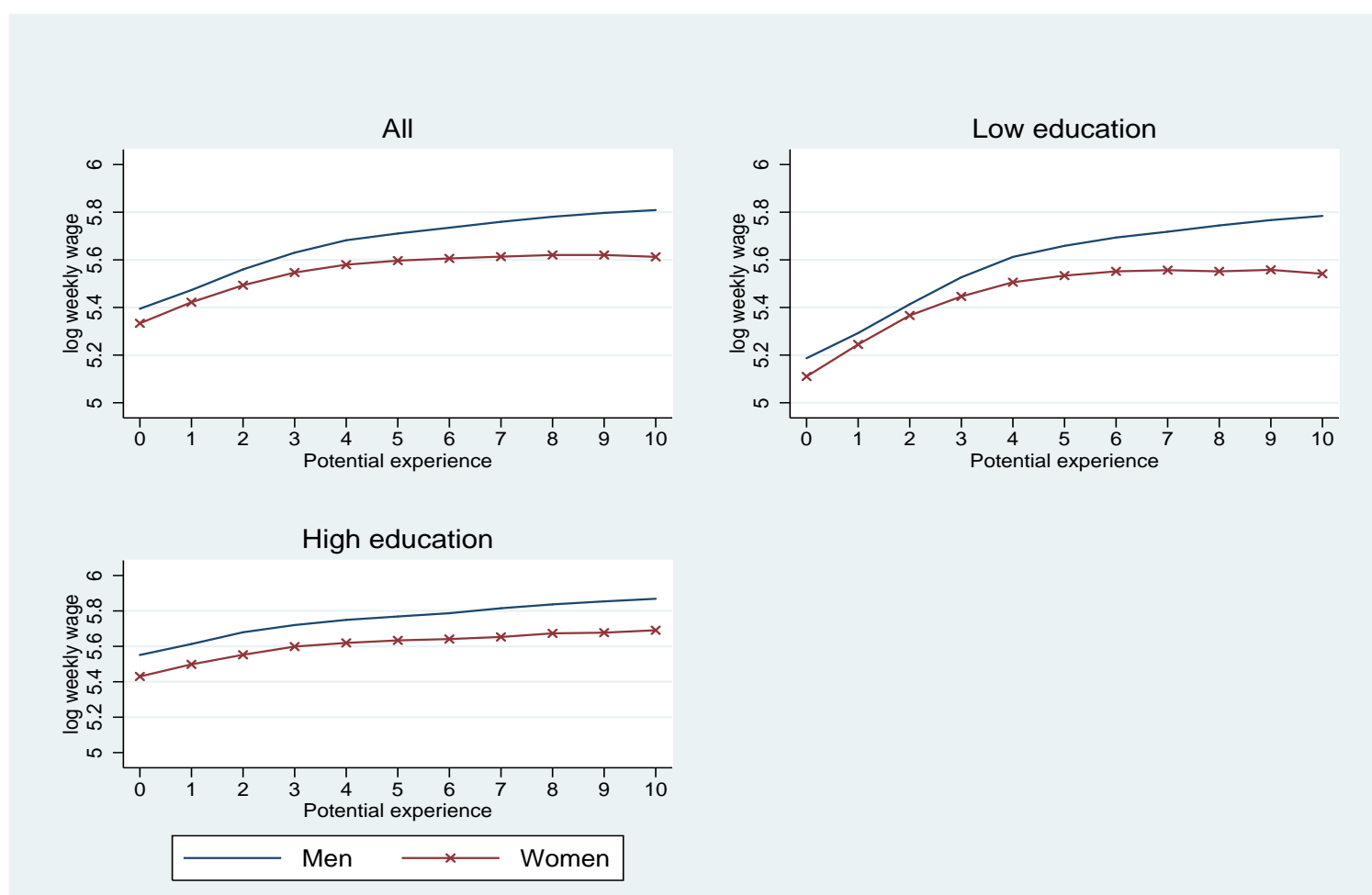

Note: Sample of individuals from the INPS administrative records for the period between 1985 and 1998 . Plot of average log real weekly wages by year of potential experience and sex. Number of observations is 159,588 for the entire sample (91,859 men and 67,729 women); 73,933 for the sub-sample of low educated individuals (48,358 men and 25,575 women); and 85,655 for the sub-sample of high educated individuals (43,501 men and 42,154 women). 
Figure 2: Log wage growth by potential experience

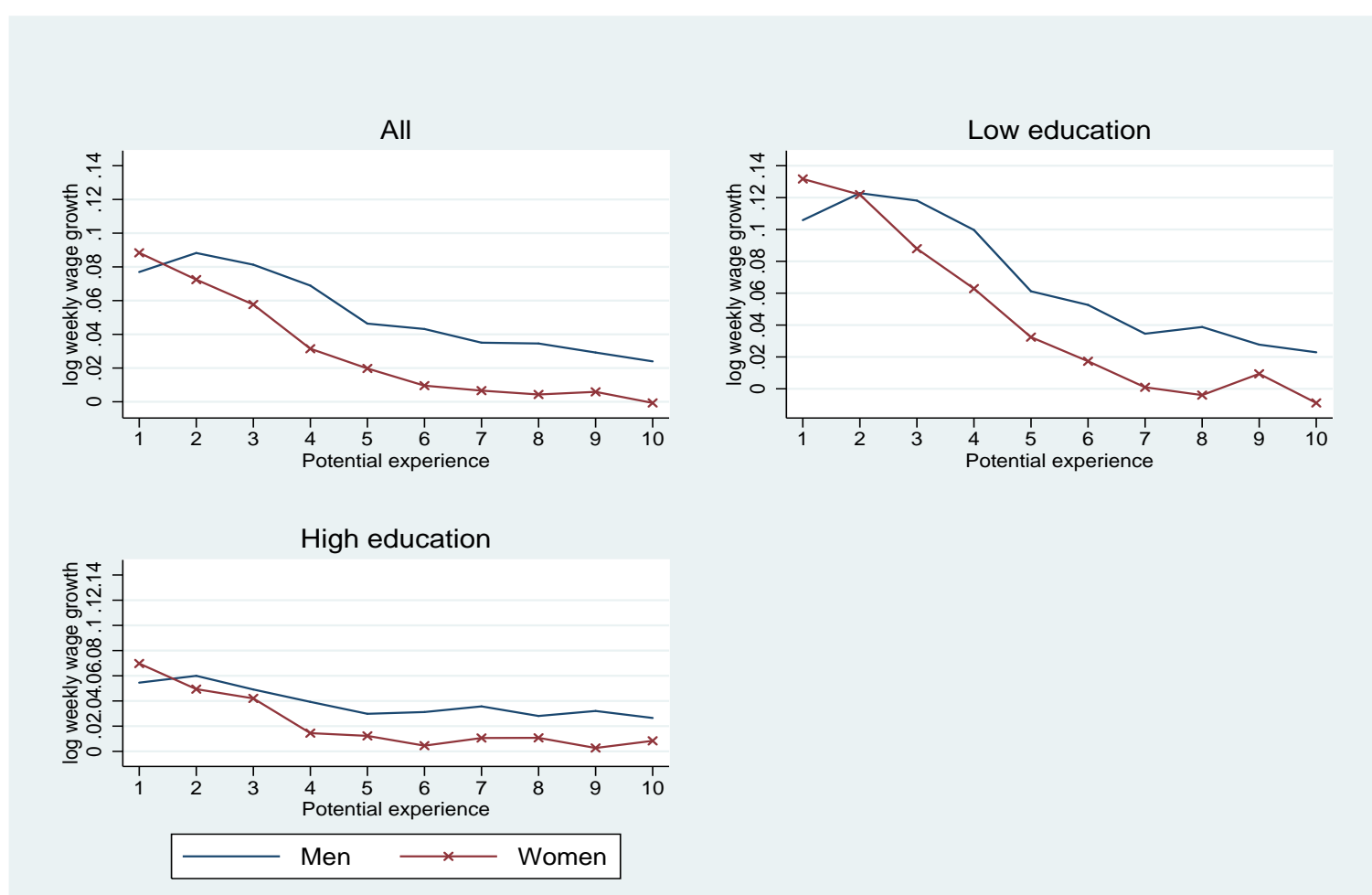

Note: Sample of individuals from the INPS administrative records for the period between 1985 and 1998 . Plot of average log real weekly wage growth by year of potential experience and sex. Number of observations is 130,485 for the entire sample ( 75,089 men and 55,396 women); 62,375 for the sub-sample of low educated individuals (40,744 men and 21,631 women); and 68,110 for the sub-sample of high educated individuals $(34,345$ men and 33,765 women). Wage growth is defined only from the second recorded spell in the data onwards. 
Figure 3: Log wage growth within-firm and between-firm by potential experience
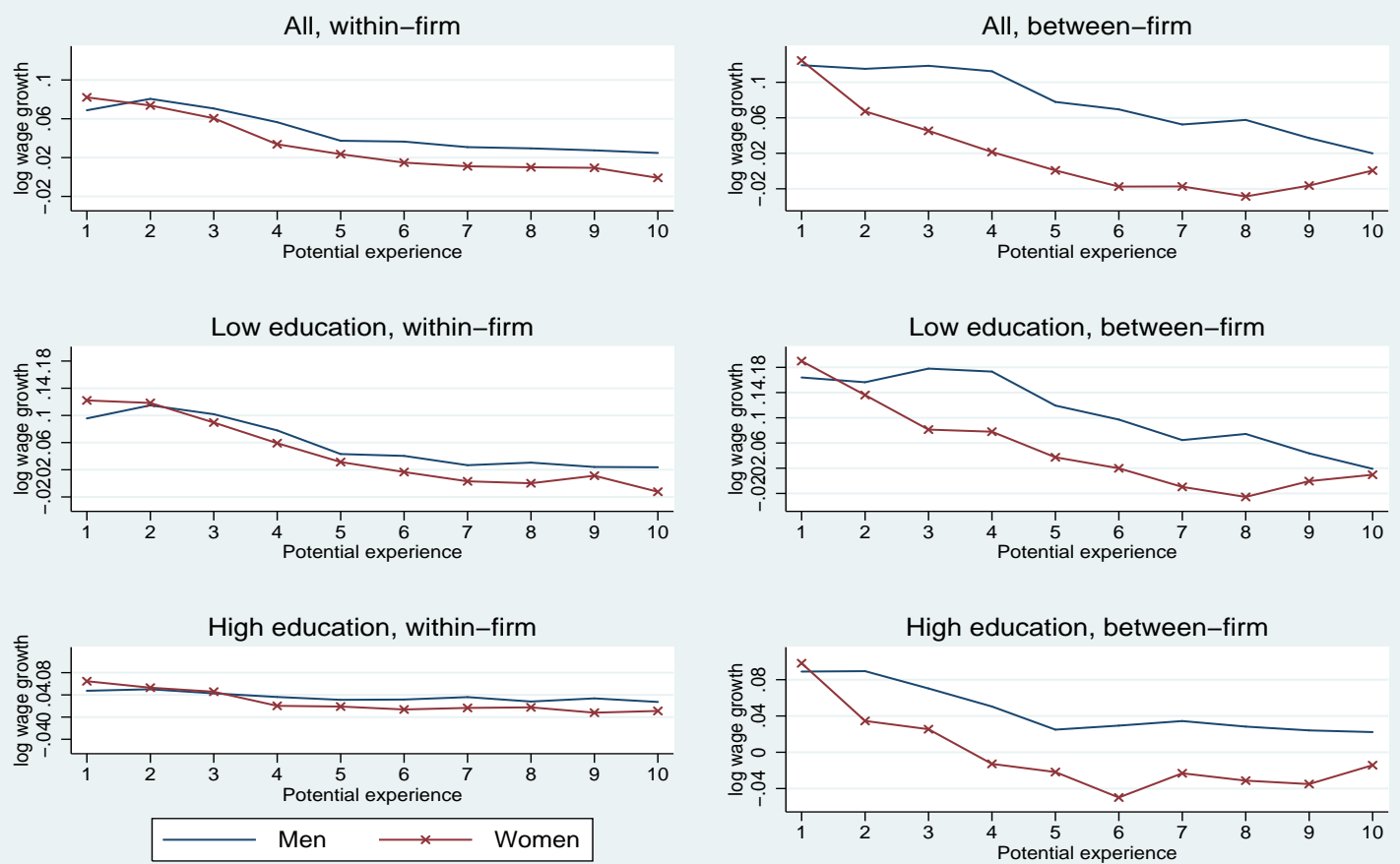

Note: Sample of individuals from the INPS administrative records for the period between 1985 and 1998. Plot of average log real weekly wage growth within-firm and between-firm by year of potential experience and sex. Number of observations is 130,485 for the entire sample (75,089 men and 55,396 women); 62,375 for the sub-sample of low educated individuals (40,744 men and 21,631 women); and 68,110 for the subsample of high educated individuals (34,345 men and 33,765 women). Wage growth is defined only from the second recorded spell in the data onwards. 
Table 1: Labor force participation rate and distribution of years between job observations by sex

All

Low education High education

\begin{tabular}{|c|c|c|c|c|c|c|}
\hline Potential experience & \multicolumn{6}{|c|}{ Percentage female } \\
\hline $\begin{array}{l}0 \\
1 \\
2 \\
3 \\
4 \\
5 \\
6 \\
7 \\
8 \\
9 \\
10 \\
\end{array}$ & \multicolumn{2}{|c|}{$\begin{array}{l}42.4 \\
43.1 \\
43.3 \\
43.0 \\
42.6 \\
42.0 \\
41.5 \\
41.1 \\
41.4 \\
41.9 \\
41.1 \\
\end{array}$} & \multicolumn{2}{|c|}{$\begin{array}{l}34.1 \\
34.4 \\
35.3 \\
35.8 \\
35.0 \\
34.3 \\
33.7 \\
34.0 \\
33.9 \\
34.8 \\
35.1 \\
\end{array}$} & \multicolumn{2}{|c|}{$\begin{array}{l}47.8 \\
48.9 \\
49.2 \\
48.7 \\
49.3 \\
49.6 \\
49.9 \\
49.6 \\
52.2 \\
54.5 \\
56.1 \\
\end{array}$} \\
\hline $\begin{array}{l}\text { Observations } \\
\text { Number of individuals }\end{array}$ & \multicolumn{2}{|c|}{$\begin{array}{l}159,588 \\
29,103\end{array}$} & \multicolumn{2}{|c|}{$\begin{array}{l}73,933 \\
11,558\end{array}$} & \multicolumn{2}{|c|}{$\begin{array}{l}85,655 \\
17,545\end{array}$} \\
\hline Years between jobs & Male & Female & Male & Female & Male & Female \\
\hline $\begin{array}{l}1 \\
2 \\
3 \\
4 \\
5 \\
6 \\
7 \\
8 \\
9 \\
\end{array}$ & $\begin{array}{c}94.1 \\
3.0 \\
1.3 \\
0.8 \\
0.4 \\
0.2 \\
0.1 \\
0.1 \\
0.0 \\
\end{array}$ & $\begin{array}{c}95.9 \\
1.9 \\
1.0 \\
0.6 \\
0.3 \\
0.2 \\
0.1 \\
0.1 \\
0.0 \\
\end{array}$ & $\begin{array}{c}94.1 \\
3.1 \\
1.3 \\
0.7 \\
0.4 \\
0.2 \\
0.1 \\
0.1 \\
0.0 \\
\end{array}$ & $\begin{array}{c}95.8 \\
2.0 \\
1.0 \\
0.5 \\
0.3 \\
0.2 \\
0.1 \\
0.1 \\
0.0 \\
\end{array}$ & $\begin{array}{c}94.1 \\
2.9 \\
1.4 \\
0.8 \\
0.4 \\
0.2 \\
0.1 \\
0.1 \\
0.0 \\
\end{array}$ & $\begin{array}{c}96.0 \\
1.8 \\
1.0 \\
0.6 \\
0.3 \\
0.2 \\
0.1 \\
0.1 \\
0.0 \\
\end{array}$ \\
\hline $\begin{array}{l}\text { Observations } \\
\text { Number of individuals }\end{array}$ & $\begin{array}{l}75,089 \\
16,770\end{array}$ & $\begin{array}{l}55,396 \\
12,333\end{array}$ & $\begin{array}{c}40,744 \\
7,614\end{array}$ & $\begin{array}{c}21,631 \\
3,944\end{array}$ & $\begin{array}{c}34,345 \\
9,156\end{array}$ & $\begin{array}{c}33,765 \\
8,389\end{array}$ \\
\hline
\end{tabular}

Notes: Sample of individuals from the INPS administrative records for the period between

1985 and 1998. Years between jobs are defined only from the second recorded spell in the data onwards. 
Table 2: Comparison of average log wage growth within firm and between firms by sex and education

\begin{tabular}{|c|c|c|c|}
\hline & Male & Female & $\begin{array}{c}\text { Difference } \\
\text { Male - Female }\end{array}$ \\
\hline \multicolumn{4}{|l|}{ Panel A: AII } \\
\hline Within-firm (1) & $\begin{array}{c}0.056 \\
(0.001)\end{array}$ & $\begin{array}{c}0.048 \\
(0.001)\end{array}$ & \multirow{3}{*}{$\begin{array}{c}0.008^{* *} \\
(0.001) \\
0.056^{* *} \\
(0.004)\end{array}$} \\
\hline Between-firm (2) & 0.091 & 0.035 & \\
\hline Difference (2)-(1) & $\begin{array}{l}(0.002) \\
0.036^{* *} \\
(0.003) \\
\end{array}$ & $\begin{array}{c}(0.004) \\
-0.012^{* *} \\
(0.004) \\
\end{array}$ & \\
\hline Observations & 75,089 & 55,396 & \\
\hline Number of individuals & 16,770 & 12,333 & \\
\hline \multicolumn{4}{|c|}{ Panel B: Low education } \\
\hline Within-firm (1) & $\begin{array}{c}0.069 \\
(0.001)\end{array}$ & $\begin{array}{c}0.062 \\
(0.001)\end{array}$ & \multirow{4}{*}{$\begin{array}{c}0.007^{* *} \\
(0.002) \\
0.051^{* *} \\
(0.006)\end{array}$} \\
\hline Between-firm (2) & 0.119 & 0.068 & \\
\hline & $(0.003)$ & $(0.005)$ & \\
\hline Difference (2)-(1) & $\begin{array}{c}0.050^{* *} * \\
(0.004)\end{array}$ & $\begin{array}{c}0.006 \\
(0.006)\end{array}$ & \\
\hline Observations & 40,744 & 21,631 & \\
\hline Number of individuals & 7,614 & 3,944 & \\
\hline \multicolumn{4}{|c|}{ Panel C: High education } \\
\hline Within-firm (1) & 0.040 & 0.039 & \multirow{6}{*}{$\begin{array}{c}0.001 \\
(0.001) \\
0.046^{* *} \\
(0.006)\end{array}$} \\
\hline & $(0.001)$ & $(0.001)$ & \\
\hline Between-firm (2) & 0.059 & 0.013 & \\
\hline & $(0.004)$ & $(0.005)$ & \\
\hline Difference (2)-(1) & $0.019^{* *}$ & $-0.026^{* *}$ & \\
\hline & $(0.004)$ & $(0.005)$ & \\
\hline Observations & 34,345 & 33,765 & \\
\hline Number of individuals & 9,156 & 8,389 & \\
\hline
\end{tabular}

Notes: Sample of individuals from the INPS administrative records for the period between 1985 and 1998. Standard errors adjusted in order to take into account the presence of multiple observations for each individual shown in parentheses. Symbols:

** significant at $1 \% ;{ }^{*}$ significant at $5 \%$. 


\begin{tabular}{|c|c|c|c|c|c|c|c|c|c|}
\hline & \multicolumn{3}{|c|}{ All } & \multicolumn{3}{|c|}{ Low education } & \multicolumn{3}{|c|}{ High education } \\
\hline & (i) & (ii) & (iii) & (i) & (ii) & (iii) & (i) & (ii) & (iii) \\
\hline Female & $-0.013^{* *}$ & $-0.007 * *$ & $-0.006^{* *}$ & $-0.010^{* *}$ & $-0.005^{* *}$ & -0.003 & $-0.015^{* *}$ & $-0.010 * *$ & $-0.008 * *$ \\
\hline Change of firm & & $\begin{array}{l}-0.003 \\
(0.002)\end{array}$ & $\begin{array}{l}-0.001 \\
(0.003)\end{array}$ & & $\begin{array}{c}-0.000 \\
(0.003)\end{array}$ & $\begin{array}{c}0.000 \\
(0.003)\end{array}$ & & $\begin{array}{c}-0.008^{*} \\
(0.004)\end{array}$ & $\begin{array}{c}-0.004 \\
(0.004)\end{array}$ \\
\hline \multirow[t]{2}{*}{ Female* change of firm } & & $-0.033^{* *}$ & $-0.034^{* *}$ & & $-0.027 * *$ & $-0.029 * *$ & & $-0.032 * *$ & $-0.034^{* *}$ \\
\hline & & $(0.004)$ & $(0.004)$ & & $(0.006)$ & $(0.006)$ & & $(0.005)$ & $(0.005)$ \\
\hline \multirow[t]{2}{*}{ Change of job (within the same firm) } & & & $0.014^{* *}$ & & & 0.004 & & & $0.024^{* *}$ \\
\hline & & & $(0.002)$ & & & $(0.004)$ & & & $(0.003)$ \\
\hline Female* change of job (within the same firm) & & & $\begin{array}{c}-0.012^{* *} \\
(0.004)\end{array}$ & & & $\begin{array}{c}-0.010 \\
(0.006)\end{array}$ & & & $\begin{array}{c}-0.016^{* *} \\
(0.005)\end{array}$ \\
\hline \multirow[t]{2}{*}{ Years between jobs } & $0.013^{* *}$ & $0.016^{* *}$ & $0.015^{* *}$ & $0.025^{* *}$ & $0.027 * *$ & $0.026^{* *}$ & 0.002 & $0.006^{*}$ & $0.005^{*}$ \\
\hline & $(0.002)$ & $(0.002)$ & $(0.002)$ & $(0.003)$ & $(0.003)$ & $(0.003)$ & $(0.003)$ & $(0.003)$ & $(0.003)$ \\
\hline \multirow[t]{2}{*}{ Potential experience at previous job } & $-0.009^{* *}$ & $-0.009^{* *}$ & $-0.009^{* *}$ & $-0.013^{* *}$ & $-0.013^{* *}$ & $-0.013^{* *}$ & $-0.007^{* *}$ & $-0.007^{*} *$ & $-0.008^{* *}$ \\
\hline & $(0.001)$ & $(0.001)$ & $(0.001)$ & $(0.001)$ & $(0.001)$ & $(0.001)$ & $(0.001)$ & $(0.001)$ & $(0.001)$ \\
\hline \multirow[t]{2}{*}{ Potential experience at previous job ${ }^{2}$} & $0.007^{* *}$ & $0.007^{* *}$ & $0.007^{* *}$ & $0.011^{* *}$ & $0.011^{* *}$ & $0.011^{* *}$ & $0.006^{* *}$ & $0.006^{* *}$ & $0.006^{* *}$ \\
\hline & $(0.001)$ & $(0.001)$ & $(0.001)$ & $(0.001)$ & $(0.001)$ & $(0.001)$ & $(0.001)$ & $(0.001)$ & $(0.001)$ \\
\hline \multirow[t]{2}{*}{ Tenure at previous job } & $-0.008^{* *}$ & $-0.009^{* *}$ & $-0.008^{* *}$ & $-0.009^{* *}$ & $-0.010^{* *}$ & $-0.010^{* *}$ & $-0.007^{* *}$ & $-0.008^{* *}$ & $-0.007^{* *}$ \\
\hline & $(0.001)$ & $(0.001)$ & $(0.001)$ & $(0.001)$ & $(0.001)$ & $(0.001)$ & $(0.001)$ & $(0.001)$ & $(0.002)$ \\
\hline \multirow[t]{2}{*}{ Tenure at previous job ${ }^{2}$} & $0.001^{* *}$ & $0.001^{* *}$ & $0.001^{* *}$ & $0.001^{* *}$ & $0.001^{* *}$ & $0.001^{* *}$ & $0.001^{* *}$ & $0.001^{* *}$ & $0.001^{* *}$ \\
\hline & $(0.000)$ & $(0.000)$ & $(0.000)$ & $(0.000)$ & $(0.000)$ & $(0.000)$ & $(0.000)$ & $(0.000)$ & $(0.000)$ \\
\hline \multirow[t]{2}{*}{ Part-time } & $-0.426^{* *}$ & $-0.425^{* *}$ & $-0.425^{* *}$ & $-0.424^{* *}$ & $-0.422^{* *}$ & $-0.422^{* *}$ & $-0.426^{* *}$ & $-0.426^{* *}$ & $-0.426^{* *}$ \\
\hline & $(0.007)$ & $(0.007)$ & $(0.007)$ & $(0.013)$ & $(0.013)$ & $(0.013)$ & $(0.009)$ & (0.009) & $(0.009)$ \\
\hline Occupation: white collar & $0.047^{* *}$ & $0.047^{* *}$ & $0.047^{* *}$ & 0.018 & 0.018 & 0.019 & $0.060^{* *}$ & $0.061^{* *}$ & $0.060^{* *}$ \\
\hline \multirow[t]{2}{*}{ Occupation: apprentice not insured } & $-0.172^{* *}$ & $-0.175^{* *}$ & $-0.173^{* *}$ & $-0.178^{* *}$ & $\begin{array}{c}(0.011) \\
-0.179 * *\end{array}$ & $\begin{array}{c}(0.011) \\
-0.179 * *\end{array}$ & $-0.134^{* *}$ & $-0.141^{* *}$ & $\begin{array}{c}0.007 \\
-0.139 * *\end{array}$ \\
\hline & $(0.012)$ & $(0.012)$ & $(0.012)$ & $(0.013)$ & $(0.013)$ & $(0.013)$ & $(0.025)$ & $(0.025)$ & $(0.025)$ \\
\hline \multirow[t]{2}{*}{ Occupation: apprentice insured } & $-0.180^{* *}$ & $-0.182^{* *}$ & $-0.180^{* *}$ & $-0.181^{* *}$ & $-0.182^{* *}$ & $-0.181^{* *}$ & $-0.168^{* *}$ & $-0.174^{* *}$ & $-0.171^{* *}$ \\
\hline & $(0.005)$ & $(0.005)$ & $(0.005)$ & $(0.005)$ & $(0.005)$ & $(0.005)$ & $(0.010)$ & $(0.010)$ & $(0.010)$ \\
\hline \multirow[t]{2}{*}{ Occupation: apprentice blue collar } & $-0.053^{* *}$ & $-0.057^{* *} *$ & $-0.058^{* *}$ & $-0.051^{* *}$ & $-0.053^{* *}$ & $-0.053^{* *}$ & $-0.035^{* *}$ & $-0.043^{* *}$ & $-0.046^{* *}$ \\
\hline & $(0.005)$ & $(0.005)$ & $(0.005)$ & $(0.005)$ & $(0.005)$ & $(0.005)$ & $(0.013)$ & $(0.013)$ & $(0.013)$ \\
\hline \multirow[t]{2}{*}{ Occupation: apprentice white collar } & -0.017 & $-0.022^{*}$ & $-0.022^{*}$ & -0.011 & -0.015 & -0.014 & -0.011 & -0.020 & -0.022 \\
\hline & $(0.009)$ & $(0.009)$ & $(0.009)$ & $(0.012)$ & $(0.012)$ & $(0.012)$ & $(0.015)$ & $(0.015)$ & $(0.015)$ \\
\hline \multirow[t]{2}{*}{ Firm size: 5-14 employees } & $0.018^{* *}$ & $0.019^{* *}$ & $0.020 * *$ & $0.023^{* *}$ & $0.024^{* *}$ & $0.024^{* *}$ & $0.013^{* *}$ & $0.014^{* *}$ & $0.014^{* *}$ \\
\hline & $(0.003)$ & $(0.003)$ & $(0.003)$ & $(0.004)$ & $(0.004)$ & $(0.004)$ & $(0.004)$ & $(0.004)$ & $(0.004)$ \\
\hline \multirow[t]{2}{*}{ Firm size: 15-99 employees } & $0.049 * *$ & $0.051^{* *}$ & $0.052^{* *}$ & $0.065^{* *}$ & $0.067^{* *}$ & $0.067^{* *}$ & $0.031^{* *}$ & $0.035^{* *}$ & $0.035^{* *}$ \\
\hline & $(0.004)$ & $(0.004)$ & $(0.004)$ & $(0.005)$ & $(0.005)$ & $(0.005)$ & $(0.006)$ & $(0.006)$ & $(0.006)$ \\
\hline \multirow[t]{2}{*}{ Firm size: $100+$ employees } & $0.102^{* *}$ & $0.107^{* *}$ & $0.107^{* *}$ & $0.133^{* *}$ & $0.137^{* *}$ & $0.137^{* *}$ & $0.077^{* *}$ & $0.083^{* *}$ & $0.083^{* *}$ \\
\hline & $(0.006)$ & $(0.006)$ & $(0.006)$ & $(0.008)$ & $(0.008)$ & $(0.008)$ & $(0.008)$ & $(0.008)$ & $(0.008)$ \\
\hline High education & $\begin{array}{c}-0.006 * * \\
(0.001)\end{array}$ & $\begin{array}{c}-0.006^{* *} \\
(0.001)\end{array}$ & $\begin{array}{c}-0.006^{* *} \\
(0.001)\end{array}$ & & & & & & \\
\hline \multirow[t]{2}{*}{ Initial contract as apprentice } & 0.001 & 0.001 & 0.001 & 0.001 & 0.001 & 0.001 & $0.006^{* *}$ & $0.006^{* *}$ & $0.006^{* *}$ \\
\hline & $(0.001)$ & $(0.001)$ & $(0.001)$ & $(0.002)$ & $(0.002)$ & $(0.002)$ & $(0.002)$ & $(0.002)$ & $(0.002)$ \\
\hline Observations & & 130,485 & & & 62,375 & & & 68,110 & \\
\hline Number of individuals & & 29,103 & & & 11,558 & & & 17,545 & \\
\hline
\end{tabular}

Notes: Sample of individuals from the INPS administrative records for the period between 1985 and 1998 . Dependent variable is the difference in log real weekly wages between year $t$ and year $t+g$. Estimation is by OLS. Control variables (some of which shown) include: a quadratic term in potential experience at time $t$, a quadratic term in years of tenure at time $t$, a linear term in years between jobs, a full set of dummies at time $t$ and $t+g$ for part-time status, occupation (omitted category: blue collar), firm size (omitted category: 0-4 employees), age of the firm, sector of activity, and region, a high education dummy (All sample), a dummy for initial contract as apprentice, plus a full set of year dummies. Huber-White heteroskedasticity robust standard errors adjusted in order to take into account the presence of multiple observations for each individual shown in parentheses. Symbols: $* *$ significant at $1 \%$; ${ }^{*}$ significant at $5 \%$. 
Table 4: Log wage growth gender differential and individual fixed-effects

\begin{tabular}{|c|c|c|c|c|c|c|c|c|c|}
\hline & \multicolumn{3}{|c|}{ All } & \multicolumn{3}{|c|}{ Low education } & \multicolumn{3}{|c|}{ High education } \\
\hline & OLS & $\mathrm{FE}$ & OLS & OLS & $\mathrm{FE}$ & OLS & OLS & $\mathrm{FE}$ & OLS \\
\hline & (i) & (ii) & (iii) & (i) & (ii) & (iii) & (i) & (ii) & (iii) \\
\hline Female & $\begin{array}{c}-0.007^{* *} \\
(0.001)\end{array}$ & & $\begin{array}{c}-0.011^{* *} \\
(0.001)\end{array}$ & $\begin{array}{c}-0.005^{* *} \\
(0.002)\end{array}$ & & $\begin{array}{c}-0.007^{* *} \\
(0.002)\end{array}$ & $\begin{array}{c}-0.010^{* *} \\
(0.002)\end{array}$ & & $\begin{array}{c}-0.013^{* *} \\
(0.002)\end{array}$ \\
\hline Change of firm & -0.003 & $\begin{array}{c}0.002 \\
(0.003)\end{array}$ & -0.003 & $\begin{array}{l}0.000 \\
(0.003)\end{array}$ & $0.007^{*}$ & -0.001 & $-0.008^{*}$ & $\begin{array}{l}-0.007 \\
(0.004)\end{array}$ & $\begin{array}{l}-0.007 \\
(0.004)\end{array}$ \\
\hline Female*change of firm & $-0.033^{* *}$ & $-0.041^{* * *}$ & $-0.029^{* *}$ & $-0.027^{* *}$ & $-0.034^{* *}$ & $-0.024^{* *}$ & $-0.032^{* *}$ & $-0.040^{*} *$ & $-0.028 * *$ \\
\hline Change of firm next period & & & $\begin{array}{c}0.002 \\
(0.002)\end{array}$ & & & $\begin{array}{l}-0.002 \\
(0.003)\end{array}$ & & & $\begin{array}{l}0.006^{*} \\
(0.003)\end{array}$ \\
\hline Female*change of firm next period & & & $0.024^{* *}$ & & & $0.018^{* *}$ & & & $0.026^{* *}$ \\
\hline $\begin{array}{l}\text { Female* }{ }^{*} \text { change of firm } \\
\quad \text { - Female* change of firm next period }\end{array}$ & & & $\begin{array}{c}-0.053^{* *} \\
(0.006)\end{array}$ & & & $\begin{array}{c}-0.043^{* *} \\
(0.008)\end{array}$ & & & $\begin{array}{c}-0.054^{* *} \\
(0.008)\end{array}$ \\
\hline Observations & & 130,485 & & & 62,375 & & & 68,110 & \\
\hline Number of individuals & & 29,103 & & & 11,558 & & & 17,545 & \\
\hline
\end{tabular}

Notes: Sample of individuals from the INPS administrative records for the period between 1985 and 1998. Dependent variable is the difference in log real weekly wages between year $t$ and year $t+g$. Estimation method shown. Other control variables include: a quadratic term in potential experience at time $t$, a quadratic term in years of tenure at time $t$, a linear term in years between jobs, a full set of dummies at time $t$ and $t+g$ for part-time status, occupation, firm size, age of the firm, sector of activity, and region, a high education dummy (All sample), a dummy for initial contract as apprentice, plus a full set of year dummies. Huber-White heteroskedasticity robust standard errors adjusted in order to take into account the presence of multiple observations for each individual shown in parentheses. Symbols: $* *$ significant at $1 \%$; ${ }^{*}$ significant at $5 \%$. 
Table 5: Log wage growth gender differential by firm closure and duration of job search

All

Low education

High education

Panel A: firm closures

(i)

(ii)

(i)

(ii)

(i)

(ii)

\section{Female}

Previous firm survives

Previous firm closes down

Female*previous firm survives

Female*previous firm closes down

$\begin{array}{cc}-0.013^{* *} & -0.006^{* *} \\ (0.001) & (0.001) \\ -0.005^{*} & 0.011^{* *} \\ (0.002) & (0.003) \\ -0.003 & 0.007 \\ (0.006) & (0.007) \\ & -0.040^{* *} \\ & (0.004) \\ & -0.023^{*} \\ & (0.011)\end{array}$

Panel B: duration of the job search

Female

Change firm within 1 month

Change firm between 2 and 9 months

Change firm after 9 months or more

Female*change firm within 1 month

Female* ${ }^{*}$ hange firm between 2 and 9 months

Female ${ }^{*}$ change firm after 9 months or more

\begin{tabular}{cccccc}
$-0.013^{* *}$ & $-0.007^{* *}$ & $-0.010^{* *}$ & $-0.005^{* *}$ & $-0.015^{* *}$ & $-0.010^{* *}$ \\
$(0.001)$ & $(0.001)$ & $(0.002)$ & $(0.002)$ & $(0.001)$ & $(0.002)$ \\
$0.007^{* *}$ & $0.013^{* *}$ & $0.011^{* *}$ & $0.013^{* *}$ & 0.004 & $0.012^{*}$ \\
$(0.003)$ & $(0.003)$ & $(0.004)$ & $(0.005)$ & $(0.004)$ & $(0.005)$ \\
$-0.029^{* *}$ & $-0.024^{* *}$ & $-0.025^{* *}$ & $-0.022^{* *}$ & $-0.033^{* *}$ & $-0.027^{* *}$ \\
$(0.004)$ & $(0.004)$ & $(0.005)$ & $(0.006)$ & $(0.005)$ & $(0.007)$ \\
$-0.011^{* *}$ & $0.013^{* *}$ & 0.000 & $0.028^{* *}$ & $-0.032^{* *}$ & 0.000 \\
$(0.004)$ & $(0.005)$ & $(0.006)$ & $(0.006)$ & $(0.006)$ & $(0.007)$ \\
& $-0.013^{*}$ & & -0.006 & & $-0.016^{*}$ \\
& $(0.006)$ & & $(0.008)$ & & $(0.008)$ \\
-0.012 & & -0.008 & & -0.012 \\
& $(0.007)$ & & $(0.010)$ & & $(0.010)$ \\
& $-0.068^{* *}$ & & $-0.062^{* *}$ & & $-0.063^{* *}$ \\
$(0.008)$ & & $(0.012)$ & & $(0.011)$ \\
\hline \multirow{2}{*}{130,485} & & 62,375 & 68,110 \\
29,103 & 11,558 & 17,545
\end{tabular}

Observations

Number of individuals

29,103

$\begin{array}{llll}-0.010^{* *} & -0.003 & -0.016^{* *} & -0.010^{* *}\end{array}$

$\left.\begin{array}{llll}0.002 & (0.002) & (0.001) & (0.002\end{array}\right)$

$\begin{array}{llll}0.008^{*} & 0.020^{* *} & -0.018^{* *} & -0.003\end{array}$

$\begin{array}{cccc}0.008^{*} & 0.020^{* *} & -0.018^{* *} & -0.003 \\ (0.003) & (0.004) & (0.003) & (0.004)\end{array}$

$\begin{array}{llll}-0.004 & 0.007 & -0.005 & 0.005\end{array}$

$\begin{array}{llll}(0.008) & (0.010) & (0.007) & (0.010)\end{array}$

$\begin{array}{ll}-0.037^{* *} & -0.034^{* *} \\ - & (0.006)\end{array}$

$(0.006) \quad(0.006)$

$\begin{array}{ll}(0.006) & (0.006) \\ -0.026 & -0.020\end{array}$

$\begin{array}{ll}-0.026 & -0.020 \\ (0.016) & (0.014)\end{array}$

Notes: Sample of individuals from the INPS administrative records for the period between 1985 and 1998 . Dependent variable is the difference in log real weekly wages between year $t$ and year $t+g$. Estimation is by OLS. Other control variables include: a quadratic term in potential experience at time $t$, a quadratic term in years of tenure at time $t$, a full set of dummies at time $t$ and $t+g$ for part-time status, occupation, firm size, age of the firm, sector of activity, and region, a high education dummy (All sample), a dummy for initial contract as apprentice, plus a full set of year dummies. Huber-White heteroskedasticity robust standard errors adjusted in order to take into account the presence of multiple observations for each individual shown in parentheses. Symbols: ** significant at $1 \%$; ${ }^{*}$ significant at $5 \%$. 
Table 6: Log wage growth gender differential by quantile

0.25 perc

0.50 perc

0.75 perc

\begin{tabular}{|c|c|c|c|c|c|c|}
\hline & (i) & (ii) & (i) & (ii) & (i) & (ii) \\
\hline \multicolumn{7}{|l|}{ Panel A: AII } \\
\hline $\begin{array}{l}\text { Female } \\
\text { Change of firm between } t-1 \text { and } t \\
\text { Female* change of firm between } t-1 \text { and } t\end{array}$ & $\begin{array}{c}-0.006^{* *} \\
(0.001) \\
-0.094^{* *} \\
(0.002)\end{array}$ & $\begin{array}{c}-0.003^{* *} \\
(0.001) \\
-0.083^{* *} \\
(0.003) \\
-0.029^{* *} \\
(0.004) \\
\end{array}$ & $\begin{array}{c}-0.008^{* *} \\
(0.001) \\
-0.011^{* *} \\
(0.002)\end{array}$ & $\begin{array}{c}-0.006^{* *} \\
(0.001) \\
0.002 \\
(0.002) \\
-0.029^{* *} \\
(0.004) \\
\end{array}$ & $\begin{array}{c}-0.012^{* *} \\
(0.001) \\
0.065^{* *} \\
(0.002)\end{array}$ & $\begin{array}{c}-0.009 * * \\
(0.001) \\
0.080 * * \\
(0.003) \\
-0.038^{* *} \\
(0.005) \\
\end{array}$ \\
\hline $\begin{array}{l}\text { Observations } \\
\text { Number of individuals }\end{array}$ & \multicolumn{6}{|c|}{$\begin{array}{l}130,485 \\
29,103\end{array}$} \\
\hline \multicolumn{7}{|l|}{ Panel B: Low education } \\
\hline $\begin{array}{l}\text { Female } \\
\text { Change of firm between } t-1 \text { and } t \\
\text { Female* change of firm between } t-1 \text { and } t\end{array}$ & $\begin{array}{c}-0.004^{*} \\
(0.002) \\
-0.089^{*} * \\
(0.003)\end{array}$ & $\begin{array}{c}-0.001 \\
(0.002) \\
-0.080^{* *} \\
(0.004) \\
-0.026^{* *} \\
(0.007)\end{array}$ & $\begin{array}{c}-0.008^{* *} \\
(0.001) \\
-0.007^{*} \\
(0.003)\end{array}$ & $\begin{array}{c}-0.006^{* *} \\
(0.001) \\
0.002 \\
(0.003) \\
-0.024^{* *} \\
(0.005)\end{array}$ & $\begin{array}{c}-0.014^{* *} \\
(0.002) \\
0.072^{* *} \\
(0.003)\end{array}$ & $\begin{array}{c}-0.009^{* *} \\
(0.002) \\
0.085^{* *} \\
(0.004) \\
-0.041^{* *} \\
(0.006)\end{array}$ \\
\hline
\end{tabular}

\begin{tabular}{ll}
\hline Observations & 62,375 \\
Number of individuals & 11,558
\end{tabular}

\begin{tabular}{|c|c|c|c|c|c|c|}
\hline \multicolumn{7}{|l|}{ Panel C: High education } \\
\hline $\begin{array}{l}\text { Female } \\
\text { Change of firm between } t-1 \text { and } t \\
\text { Female* change of firm between } t-1 \text { and } t\end{array}$ & $\begin{array}{c}-0.006^{* *} \\
(0.001) \\
-0.098^{* *} \\
(0.004)\end{array}$ & $\begin{array}{c}-0.005^{* *} \\
(0.001) \\
-0.086^{* *} \\
(0.004) \\
-0.026^{* *} \\
(0.007) \\
\end{array}$ & $\begin{array}{c}-0.007^{* *} \\
(0.001) \\
-0.015^{* *} \\
(0.002)\end{array}$ & $\begin{array}{c}-0.005^{* *} \\
(0.001) \\
-0.002 \\
(0.003) \\
-0.028^{* *} \\
(0.004) \\
\end{array}$ & $\begin{array}{c}-0.010^{* *} \\
(0.002) \\
0.058^{* *} \\
(0.003)\end{array}$ & $\begin{array}{c}-0.007^{* *} \\
(0.002) \\
0.072^{* *} \\
(0.004) \\
-0.030^{* *} \\
(0.006) \\
\end{array}$ \\
\hline $\begin{array}{l}\text { Observations } \\
\text { Number of individuals }\end{array}$ & & & & & & \\
\hline
\end{tabular}

Notes: Sample of individuals from the INPS administrative records for the period between 1985 and 1998. Dependent variable is the difference in log real weekly wages between year $t$ and year $t+g$. Estimation method is by quantile regression. Other control variables include: a quadratic term in potential experience at time $t$, a quadratic term in years of tenure at time $t$, a linear term in years between jobs, a full set of dummies at time $t$ and $t+g$ for part-time status, occupation, firm size, age of the firm, sector of activity, and region, a high education dummy (All sample), a dummy for initial contract as apprentice, plus a full set of year dummies. Standard errors obtained by bootstrap (100 replications) in order to take into account the presence of multiple observations for each individual shown in parentheses. Symbols:

** significant at $1 \%$; significant at $5 \%$ 
Table 7: Reason for change of employer in the last 12 months, EU-Silc 2004

\begin{tabular}{lcc}
\hline \hline & Male & Female \\
\hline Found a better job & 50.2 & 44.4 \\
Temporary job ended & 27.7 & 26.0 \\
Dismissal, firm closure, early retirement & 12.1 & 12.9 \\
Sale or closure of own or family business & 2.0 & 3.3 \\
Looking after children, old, sick or disabled persons & 0.7 & 2.3 \\
Got married, partner's job required to move & 0.9 & 1.5 \\
Other & 6.5 & 9.6 \\
\hline Number of individuals & 448 & 396
\end{tabular}

Notes: Sample of individuals from the EU-Silc 2004. The sample is restricted to men and women aged

35 or below. The percentages shown refer to reason given for a change of employer occurred in the last 12 months. 
Table 8: Contribution of changes of job and firm characteristics to between-firm wage growth

\begin{tabular}{|c|c|c|c|c|c|c|c|c|c|}
\hline & \multicolumn{3}{|c|}{ All } & \multicolumn{3}{|c|}{ Low education } & \multicolumn{3}{|c|}{ High education } \\
\hline & (i) & (ii) & (iii) & (i) & (ii) & (iii) & (i) & (ii) & (iii) \\
\hline Female & $\begin{array}{c}-0.047^{* *} \\
(0.004)\end{array}$ & $\begin{array}{c}-0.034^{* *} \\
(0.004)\end{array}$ & $\begin{array}{c}0.005 \\
(0.010)\end{array}$ & $\begin{array}{c}-0.050^{* *} \\
(0.006)\end{array}$ & $\begin{array}{c}-0.035^{* *} \\
(0.006)\end{array}$ & $\begin{array}{c}0.004 \\
(0.015)\end{array}$ & $\begin{array}{c}-0.043^{* *} \\
(0.006)\end{array}$ & $\begin{array}{c}-0.032^{* *} \\
(0.005)\end{array}$ & $\begin{array}{c}0.002 \\
(0.012)\end{array}$ \\
\hline Change from part-time to full-time & & $0.437 * *$ & $\begin{array}{c}0.459^{* *} \\
(0.026)\end{array}$ & & $\begin{array}{c}0.398^{* *} \\
(0.029)\end{array}$ & $\begin{array}{c}0.411^{* *} \\
(0.044)\end{array}$ & & $\begin{array}{c}0.456^{* *} \\
(0.017)\end{array}$ & $\begin{array}{c}0.489^{* *} \\
(0.031)\end{array}$ \\
\hline Change from full-time to part-time & & $-0.491^{* *}$ & $\begin{array}{c}-0.465^{* *} \\
(0.024)\end{array}$ & & $\begin{array}{c}-0.478^{* *} \\
(0.021)\end{array}$ & $\begin{array}{c}-0.487^{*} * \\
(0.033)\end{array}$ & & $\begin{array}{c}-0.495^{* *} \\
(0.017)\end{array}$ & $\begin{array}{c}-0.455^{* *} \\
(0.034)\end{array}$ \\
\hline Change of occupation & & $\begin{array}{c}0.086^{* *} \\
(0.006)\end{array}$ & $\begin{array}{l}0.104^{* *} \\
(0.007)\end{array}$ & & $\begin{array}{l}0.114^{* *} \\
(0.007)\end{array}$ & $0.136^{* *}$ & & $0.034^{* *}$ & $0.035^{* *}$ \\
\hline Change to a larger firm & & $\begin{array}{c}0.070^{*} * \\
(0.005)\end{array}$ & $0.087^{* *}$ & & $\begin{array}{c}0.089 * * \\
(0.007)\end{array}$ & $\begin{array}{c}0.101^{* *} \\
(0.009)\end{array}$ & & $0.051^{* *}$ & $0.069^{* *} *$ \\
\hline Change to a smaller firm & & $\begin{array}{c}-0.073^{* *} \\
(0.006)\end{array}$ & $\begin{array}{c}-0.075^{* *} \\
(0.007)\end{array}$ & & $\begin{array}{c}-0.081^{* *} \\
(0.008)\end{array}$ & $\begin{array}{c}-0.082^{* *} \\
(0.010)\end{array}$ & & $\begin{array}{c}-0.067^{* *} \\
(0.008)\end{array}$ & $\begin{array}{c}-0.067^{* *} \\
(0.010)\end{array}$ \\
\hline Change to a firm with different age & & $\begin{array}{c}0.006 \\
(0.005)\end{array}$ & $\begin{array}{c}0.009 \\
(0.006)\end{array}$ & & $\begin{array}{c}0.002 \\
(0.007)\end{array}$ & $\begin{array}{c}0.003 \\
(0.008)\end{array}$ & & $\begin{array}{c}0.011 \\
(0.007)\end{array}$ & $\begin{array}{c}0.014 \\
(0.009)\end{array}$ \\
\hline Change of sector & & $-0.015^{* *}$ & $\begin{array}{c}-0.013^{* *} \\
(0.005)\end{array}$ & & $\begin{array}{c}-0.014^{*} \\
(0.006)\end{array}$ & $\begin{array}{c}-0.014^{*} \\
(0.007)\end{array}$ & & $\begin{array}{c}-0.012^{*} \\
(0.006)\end{array}$ & $\begin{array}{l}-0.006 \\
(0.008)\end{array}$ \\
\hline Change of region & & $\begin{array}{c}-0.001 \\
(0.008)\end{array}$ & $\begin{array}{c}0.010 \\
(0.010)\end{array}$ & & $\begin{array}{l}-0.008 \\
(0.013)\end{array}$ & $\begin{array}{c}0.010 \\
(0.015)\end{array}$ & & $\begin{array}{c}0.001 \\
(0.011)\end{array}$ & $\begin{array}{c}0.004 \\
(0.013)\end{array}$ \\
\hline Female*change from part-time to full-time & & & $\begin{array}{l}-0.034 \\
(0.031)\end{array}$ & & & $\begin{array}{l}-0.023 \\
(0.058)\end{array}$ & & & $\begin{array}{l}-0.049 \\
(0.037)\end{array}$ \\
\hline Female*change from full-time to part-time & & & $\begin{array}{c}-0.034 \\
(0.029)\end{array}$ & & & $\begin{array}{c}0.016 \\
(0.043)\end{array}$ & & & $\begin{array}{c}-0.054 \\
(0.039)\end{array}$ \\
\hline Female*change of occupation & & & $\begin{array}{c}-0.047^{* *} \\
(0.011)\end{array}$ & & & $\begin{array}{c}-0.065^{* *} \\
(0.015)\end{array}$ & & & $\begin{array}{c}0.000 \\
(0.016)\end{array}$ \\
\hline Female* change to a larger firm & & & $\begin{array}{c}-0.045^{* *} \\
(0.011)\end{array}$ & & & $\begin{array}{c}-0.039^{*} \\
(0.016)\end{array}$ & & & $\begin{array}{c}-0.040^{* *} \\
(0.015)\end{array}$ \\
\hline Female*change to a smaller firm & & & $\begin{array}{c}0.007 \\
(0.012)\end{array}$ & & & $\begin{array}{c}0.008 \\
(0.019)\end{array}$ & & & $\begin{array}{c}0.003 \\
(0.016)\end{array}$ \\
\hline Female*change to a firm with different age & & & $\begin{array}{c}-0.005 \\
(0.010)\end{array}$ & & & $\begin{array}{l}-0.002 \\
(0.015)\end{array}$ & & & $\begin{array}{l}-0.008 \\
(0.014)\end{array}$ \\
\hline Female*change of sector & & & $\begin{array}{c}-0.004 \\
(0.009)\end{array}$ & & & $\begin{array}{c}0.005 \\
(0.013)\end{array}$ & & & $\begin{array}{l}-0.014 \\
(0.012)\end{array}$ \\
\hline Female*change of region & & & $\begin{array}{l}-0.035 \\
(0.019) \\
\end{array}$ & & & $\begin{array}{c}-0.075^{*} \\
(0.031) \\
\end{array}$ & & & $\begin{array}{l}-0.009 \\
(0.023)\end{array}$ \\
\hline $\begin{array}{l}\text { Observations } \\
\text { Number of individu }\end{array}$ & & $\begin{array}{l}24,877 \\
14.773\end{array}$ & & & $\begin{array}{l}12,253 \\
6.639\end{array}$ & & & $\begin{array}{l}12,624 \\
8,134\end{array}$ & \\
\hline
\end{tabular}

Notes: Sample of individuals from the INPS administrative records for the period between 1985 and 1998 . Dependent variable is the difference in log real weekly wages between year $t$ and year $t+g$ for periods in which the individual changes firm. Estimation is by OLS. Other control variables include: a quadratic term in potential experience at time $t$, a quadratic term in years of tenure at time $t$, a linear term in years between jobs, a high education dummy (All sample), a dummy for initial contract as apprentice, plus a full set of year dummies. Huber-White heteroskedasticity robust standard errors adjusted in order to take into account the presence of multiple observations for each individual shown in parentheses. Symbols: ** significant at $1 \%$; ${ }^{*}$ significant at $5 \%$ 
Table 9: Contribution of average premium for changes of job and firm characteristics to between-firm wage growth

\begin{tabular}{|c|c|c|c|c|c|c|}
\hline & \multicolumn{2}{|c|}{ All } & \multicolumn{2}{|c|}{ Low education } & \multicolumn{2}{|c|}{ High education } \\
\hline & (i) & (ii) & (i) & (ii) & (i) & (ii) \\
\hline Female & $\begin{array}{c}-0.027^{* *} \\
(0.003)\end{array}$ & $\begin{array}{l}-0.006 \\
(0.005)\end{array}$ & $\begin{array}{c}-0.024^{* *} \\
(0.005)\end{array}$ & $\begin{array}{c}-0.004 \\
(0.009)\end{array}$ & $\begin{array}{c}-0.028^{* *} \\
(0.005)\end{array}$ & $\begin{array}{l}-0.011 \\
(0.006)\end{array}$ \\
\hline Occupational qualification premium & $\begin{array}{c}0.924^{* *} \\
(0.022)\end{array}$ & $\begin{array}{c}0.988^{* *} \\
(0.025)\end{array}$ & $\begin{array}{c}0.994^{* *} \\
(0.027)\end{array}$ & $\begin{array}{c}1.052^{* *} \\
(0.031)\end{array}$ & $\begin{array}{c}0.913^{* *} \\
(0.045)\end{array}$ & $\begin{array}{l}1.017^{* *} \\
(0.061)\end{array}$ \\
\hline Larger firm size premium & $\begin{array}{c}0.752^{* *} \\
(0.049)\end{array}$ & $\begin{array}{c}0.918^{* *} \\
(0.056)\end{array}$ & $\begin{array}{c}0.928^{* *} \\
(0.063)\end{array}$ & $\begin{array}{c}1.029^{* *} \\
(0.071)\end{array}$ & $\begin{array}{c}0.575^{* *} \\
(0.074)\end{array}$ & $\begin{array}{c}0.758^{* *} \\
0.088)\end{array}$ \\
\hline Smaller firm size premium & $\begin{array}{c}0.881^{* *} \\
(0.059)\end{array}$ & $\begin{array}{c}0.931^{* *} \\
(0.076)\end{array}$ & $\begin{array}{c}0.918^{* *} \\
(0.086)\end{array}$ & $\begin{array}{c}0.912^{* *} \\
(0.103)\end{array}$ & $\begin{array}{c}0.825^{* *} \\
(0.082)\end{array}$ & $\begin{array}{c}0.915^{* *} \\
(0.107)\end{array}$ \\
\hline Older/younger firm premium & $\begin{array}{c}0.625^{* *} \\
(0.151)\end{array}$ & $\begin{array}{c}0.527^{* *} \\
(0.193)\end{array}$ & $\begin{array}{c}1.079^{* *} \\
(0.525)\end{array}$ & $\begin{array}{c}0.963 \\
(0.635)\end{array}$ & $\begin{array}{c}0.507^{* *} \\
(0.187)\end{array}$ & $\begin{array}{c}0.410 \\
(0.230)\end{array}$ \\
\hline Sector premium & $\begin{array}{c}0.868^{* *} \\
(0.028)\end{array}$ & $\begin{array}{c}0.927^{* *} \\
(0.033)\end{array}$ & $\begin{array}{c}0.836^{* *} \\
(0.033)\end{array}$ & $\begin{array}{l}0.825^{* *} \\
(0.053)\end{array}$ & $\begin{array}{c}0.874^{* *} \\
(0.047)\end{array}$ & $\begin{array}{l}0.973^{* *} \\
(0.068)\end{array}$ \\
\hline Region premium & $\begin{array}{c}0.913^{* *} \\
(0.134)\end{array}$ & $\begin{array}{c}0.954^{* *} \\
(0.141)\end{array}$ & $\begin{array}{c}0.714^{* *} \\
(0.154)\end{array}$ & $\begin{array}{c}0.751^{* *} \\
(0.168)\end{array}$ & $\begin{array}{l}1.032^{* *} \\
(0.204)\end{array}$ & $\begin{array}{l}1.094^{* *} \\
(0.235)\end{array}$ \\
\hline Female*occupation premium & & $\begin{array}{c}-0.171^{* *} \\
(0.040)\end{array}$ & & $\begin{array}{c}-0.174^{* *} \\
(0.060)\end{array}$ & & $\begin{array}{c}-0.198^{*} \\
(0.070)\end{array}$ \\
\hline Female*larger firm size premium & & $\begin{array}{c}-0.450^{* *} \\
(0.084)\end{array}$ & & $\begin{array}{c}-0.359^{* * *} \\
(0.144)\end{array}$ & & $\begin{array}{c}-0.406^{* *} \\
(0.146)\end{array}$ \\
\hline Female*smaller firm size premium & & $\begin{array}{c}-0.155 \\
(0.119)\end{array}$ & & $\begin{array}{c}-0.009 \\
(0.217)\end{array}$ & & $\begin{array}{l}-0.223 \\
(0.172)\end{array}$ \\
\hline Female*older/younger firm premium & & 0.227 & & $\begin{array}{c}0.175 \\
(1.069)\end{array}$ & & $\begin{array}{c}0.190 \\
(0.355)\end{array}$ \\
\hline Female*sector premium & & $\begin{array}{c}-0.106 \\
(0.060)\end{array}$ & & $\begin{array}{c}0.038 \\
(0.091)\end{array}$ & & $\begin{array}{c}-0.172 \\
(0.080)\end{array}$ \\
\hline Female*region premium & & $\begin{array}{c}-0.337 \\
(0.366) \\
\end{array}$ & & $\begin{array}{c}-0.381 \\
(0.470) \\
\end{array}$ & & $\begin{array}{l}-0.317 \\
(0.441) \\
\end{array}$ \\
\hline Number of individuals & & & 6 & & & \\
\hline
\end{tabular}

Notes: Sample of individuals from the INPS administrative records for the period between 1985 and 1998.

Dependent variable is the difference in $\log$ real weekly wages between year $t$ and year $t+g$ for periods in which the individual changes firm. Estimation is by OLS. Other control variables include: dummies for change from part time to full time status and viceversa, a quadratic term in potential experience at time $t$, a quadratic term in years of tenure at time $t$, a linear term in years between jobs, a high education dummy (All sample), a dummy for initial contract as apprentice, plus a full set of year dummies. Standard errors obtained by bootstrap (100 replications) in order to take into account the presence of generated regressors. Symbols: ** significant at $1 \%$; significant at $5 \%$. 
Table 10: Job search, job satisfaction and firm size, 2005 ISFOL-PLUS

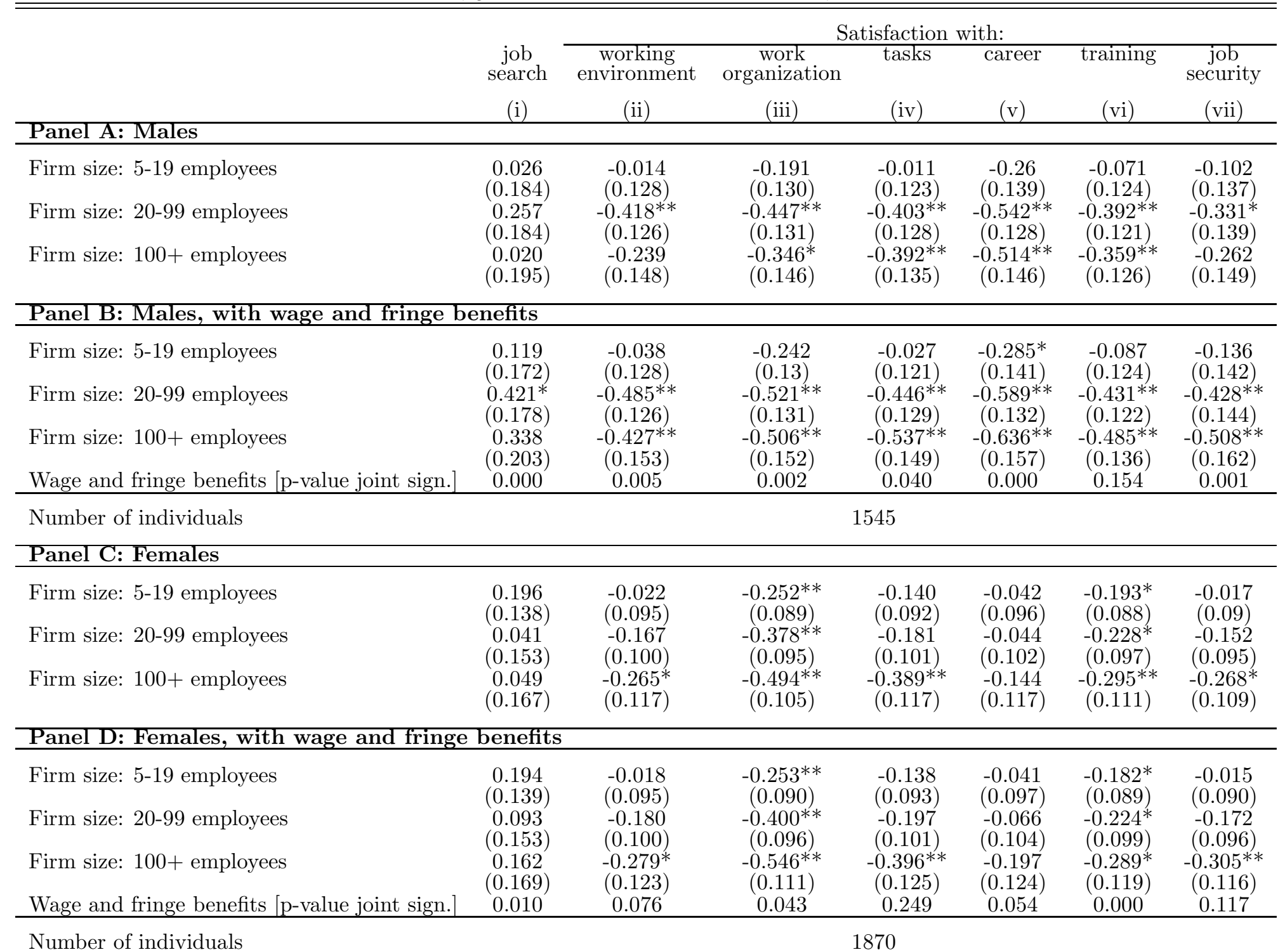

Notes: Sample of individuals from the 2005 ISFOL-Plus survey. The dependent variables are: a dummy for whether the worker is searching for another job (column (i)), and ordinal variables indicating the degree of satisfaction about the indicated aspect of the job (columns (ii)-(vii)). The numbers shown represent coefficients from a binomial probit in column (i) and ordered probits for columns (ii) to (vii). Other control variables not shown include: a quadratic term in potential experience, a quadratic term in years of tenure with the current firm, a dummy for part-time status, a full set of dummies for type of contract, shift work, fixed hours, night or weekend work, dummies for firm economic conditions (whether a merger or acquisition has occurred or the firm has been hiring in the past year), educational qualification, occupation, sector of activity, and geographic area. Data are weighted using sampling weights. Huber-White heteroskedasticity robust standard errors shown in parentheses. Symbols: ** significant at $1 \%$; ${ }^{*}$ significant at $5 \%$. 


\section{All}

Low education High education

\begin{tabular}{|c|c|c|c|c|c|c|}
\hline & Male & Female & Male & Female & Male & Female \\
\hline \multirow[t]{2}{*}{ Log weekly wage } & 5.58 & 5.50 & 5.50 & 5.40 & 5.68 & 5.56 \\
\hline & $(0.34)$ & $(0.37)$ & $(0.34)$ & $(0.35)$ & $(0.31)$ & $(0.37)$ \\
\hline \multirow[t]{2}{*}{ Log weekly wage growth ${ }^{\dagger}$} & 0.06 & 0.05 & 0.08 & 0.06 & 0.04 & 0.03 \\
\hline & $(0.23)$ & $(0.25)$ & $(0.23)$ & $(0.25)$ & $(0.22)$ & $(0.25)$ \\
\hline Changes of firm ${ }^{\dagger}$ & 0.17 & 0.14 & 0.17 & 0.15 & 0.16 & 0.13 \\
\hline Changes of job (within the same firm) ${ }^{\dagger}$ & 0.09 & 0.09 & 0.09 & 0.09 & 0.09 & 0.09 \\
\hline \multirow[t]{2}{*}{ Years between jobs ${ }^{\dagger}$} & 1.12 & 1.09 & 1.12 & 1.09 & 1.12 & 1.09 \\
\hline & $(0.60)$ & $(0.53)$ & $(0.59)$ & $(0.52)$ & $(0.60)$ & $(0.53)$ \\
\hline \multirow[t]{2}{*}{ Years of potential experience } & 3.30 & 3.24 & 3.73 & 3.72 & 2.83 & 2.96 \\
\hline & $(2.81)$ & $(2.78)$ & $(2.96)$ & $(2.95)$ & $(2.56)$ & $(2.64)$ \\
\hline \multirow[t]{2}{*}{ Years of tenure } & 1.03 & 1.18 & 1.14 & 1.32 & 0.92 & 1.09 \\
\hline & $(1.63)$ & $(1.78)$ & $(1.69)$ & $(1.88)$ & $(1.56)$ & $(1.71)$ \\
\hline Part-time & 0.03 & 0.12 & 0.01 & 0.06 & 0.04 & 0.15 \\
\hline Occupation: blue collar (reference category) & 0.62 & 0.38 & 0.53 & 0.44 & 0.72 & 0.34 \\
\hline Occupation: white collar & 0.12 & 0.42 & 0.03 & 0.14 & 0.22 & 0.58 \\
\hline Occupation: apprentice not insured & 0.01 & 0.01 & 0.02 & 0.02 & 0.00 & 0.01 \\
\hline Occupation: apprentice insured & 0.23 & 0.17 & 0.38 & 0.34 & 0.06 & 0.07 \\
\hline Occupation: apprentice blue collar & 0.03 & 0.02 & 0.05 & 0.04 & 0.01 & 0.01 \\
\hline Occupation: apprentice white collar & 0.00 & 0.01 & 0.00 & 0.01 & 0.00 & 0.00 \\
\hline Firm size: 0-4 employees (reference category) & 0.28 & 0.30 & 0.34 & 0.31 & 0.22 & 0.30 \\
\hline Firm size: 5-14 employees & 0.27 & 0.25 & 0.31 & 0.29 & 0.24 & 0.23 \\
\hline Firm size: 15-99 employees & 0.28 & 0.27 & 0.25 & 0.29 & 0.30 & 0.26 \\
\hline Firm size: $100+$ employees & 0.17 & 0.17 & 0.11 & 0.10 & 0.24 & 0.22 \\
\hline Initial contract as apprentice & 0.48 & 0.39 & 0.79 & 0.77 & 0.14 & 0.16 \\
\hline Observations & 91,859 & 67,729 & 48,358 & 25,575 & 43,501 & 42,154 \\
\hline Number of individuals & 16,770 & 12,333 & 7,614 & 3,944 & 9,156 & 8,389 \\
\hline
\end{tabular}

Notes: Sample of individuals from the INPS administrative records for the period between 1985 and 1998. Variable means (standard deviations of continuous variables are in parentheses). Symbols: ${ }^{\dagger}$ defined only from the second recorded spell in the data onwards. 


\section{CESifo Working Paper Series}

for full list see www.cesifo-group.org/wp

(address: Poschingerstr. 5, 81679 Munich, Germany, office@cesifo.de)

2373 David Anthoff and Richard S.J. Tol, On International Equity Weights and National Decision Making on Climate Change, August 2008

2374 Florian Englmaier and Arno Schmöller, Reserve Price Formation in Online Auctions, August 2008

2375 Karl Farmer, Birgit Friedl and Andreas Rainer, Effects of Unilateral Climate Policy on Terms of Trade, Capital Accumulation, and Welfare in a World Economy, August 2008

2376 Monika Bütler, Stefan Staubli and Maria Grazia Zito, The Role of the Annuity's Value on the Decision (Not) to Annuitize: Evidence from a Large Policy Change, August 2008

2377 Inmaculada Martínez-Zarzoso, The Impact of Urbanization on $\mathrm{CO}_{2}$ Emissions: Evidence from Developing Countries, August 2008

2378 Brian Roberson and Dmitriy Kvasov, The Non-Constant-Sum Colonel Blotto Game, August 2008

2379 Ian Dew-Becker, How Much Sunlight Does it Take to Disinfect a Boardroom? A Short History of Executive Compensation Regulation, August 2008

2380 Cécile Aubert, Oliver Falck and Stephan Heblich, Subsidizing National Champions: An Evolutionary Perspective, August 2008

2381 Sebastian Buhai, Miguel Portela, Coen Teulings and Aico van Vuuren, Returns to Tenure or Seniority?, August 2008

2382 Erkki Koskela and Jan König, Flexible Outsourcing, Profit Sharing and Equilibrium Unemployment, August 2008

2383 Torberg Falch and Justina AV Fischer, Does a Generous Welfare State Crowd out Student Achievement? Panel Data Evidence from International Student Tests, September 2008

2384 Pedro Gomes and François Pouget, Corporate Tax Competition and the Decline of Public Investment, September 2008

2385 Marko Koethenbuerger, How Do Local Governments Decide on Public Policy in Fiscal Federalism? Tax vs. Expenditure Optimization, September 2008

2386 Ronald McKinnon and Gunther Schnabl, China's Exchange Rate Impasse and the Weak U.S. Dollar, September 2008

2387 Yan-Leung Cheung, Yin-Wong Cheung and Alan T.K. Wan, A High-Low Model of Daily Stock Price Ranges, September 2008 
2388 Louis Eeckhoudt and Harris Schlesinger, Changes in Risk and the Demand for Saving, September 2008

2389 Carsten Hefeker and Blandine Zimmer, Uncertainty and Fiscal Policy in an Asymmetric Monetary Union, September 2008

2390 Jay Pil Choi and Byung-Cheol Kim, Net Neutrality and Investment Incentives, September 2008

2391 Marcel Gérard, Financing Bologna, the Internationally Mobile Students in European Higher Education, September 2008

2392 Annette Alstadsæter and Knut Reidar Wangen, Corporations' Choice of Tax Regime when Transition Costs are Small and Income Shifting Potential is Large, September 2008

2393 António Afonso and Christophe Rault, 3-Step Analysis of Public Finances Sustainability: the Case of the European Union, September 2008

2394 Betsey Stevenson and Justin Wolfers, Economic Growth and Subjective Well-Being: Reassessing the Easterlin Paradox, September 2008

2395 Bernhard Eckwert and Itzhak Zilcha, Private Investment in Higher Education: Comparing Alternative Funding Schemes, September 2008

2396 Øystein Foros, Hans Jarle Kind and Jan Yngve Sand, Slotting Allowances and Manufacturers' Retail Sales Effort, September 2008

2397 Mohammad Reza Farzanegan, Illegal Trade in the Iranian Economy: Evidence from a Structural Model, September 2008

2398 Olivier Bos, Charity Auctions for the Happy Few, September 2008

2399 Robert S. Chirinko and Debdulal Mallick, The Marginal Product of Capital: A Persistent International Puzzle, September 2008

2400 Ben D'Exelle and Arno Riedl, Elite Capture, Political Voice and Exclusion from Aid: An Experimental Study, September 2008

2401 Torben M. Andersen and Joydeep Bhattacharya, On Myopia as Rationale for Social Security, September 2008

2402 Fabienne Llense, French CEO Compensations: What is the Cost of a Mandatory Upper Limit?, September 2008

2403 Valentina Bosetti, Carlo Carraro, Alessandra Sgobbi and Massimo Tavoni, Delayed Action and Uncertain Targets. How Much Will Climate Policy Cost?, September 2008

2404 Robert G. Chambers, Rolf Färe, Shawna Grosskopf and Michael Vardanyan, Generalized Quadratic Revenue Functions, September 2008 
2405 Leonidas Enrique de la Rosa, Overconfidence in a Career-Concerns Setting, September 2008

2406 Marcus Drometer and Johannes Rincke, The Design of Political Institutions: Electoral Competition and the Choice of Ballot Access Restrictions in the United States, September 2008

2407 Markku Lanne and Helmut Lütkepohl, Stock Prices and Economic Fluctuations: A Markov Switching Structural Vector Autoregressive Analysis, September 2008

2408 Thomas L. Brewer, International Energy Technology Transfers for Climate Change Mitigations, September 2008

2409 Alexander Kemnitz, Native Welfare Losses from High Skilled Immigration, September 2008

2410 Xavier Vives, Strategic Supply Function Competition with Private Information, September 2008

2411 Fabio Padovano and Roberto Ricciuti, The Political Competition-Economic Performance Puzzle: Evidence from the OECD Countries and the Italian Regions, September 2008

2412 Joan Costa-Font and Mireia Jofre-Bonet, Body Image and Food Disorders: Evidence from a Sample of European Women, September 2008

2413 Thorsten Upmann, Labour Unions - To Unite or to Separate?, October 2008

2414 Sascha O. Becker and Ludger Woessmann, Luther and the Girls: Religious Denomination and the Female Education Gap in $19^{\text {th }}$ Century Prussia, October 2008

2415 Florian Englmaier and Stephen Leider, Contractual and Organizational Structure with Reciprocal Agents, October 2008

2416 Vittorio Daniele and Ugo Marani, Organized Crime and Foreign Direct Investment: The Italian Case, October 2008

2417 Valentina Bosetti, Carlo Carraro, Alessandra Sgobbi and Massimo Tavoni, Modelling Economic Impacts of Alternative International Climate Policy Architectures. A Quantitative and Comparative Assessment of Architectures for Agreement, October 2008

2418 Paul De Grauwe, Animal Spirits and Monetary Policy, October 2008

2419 Guglielmo Maria Caporale, Christophe Rault, Robert Sova and Anamaria Sova, On the Bilateral Trade Effects of Free Trade Agreements between the EU-15 and the CEEC-4 Countries, October 2008

2420 Yin-Wong Cheung and Daniel Friedman, Speculative Attacks: A Laboratory Study in Continuous Time, October 2008 
2421 Kamila Fialová and Ondřej Schneider, Labour Market Institutions and their Effect on Labour Market Performance in the New EU Member Countries, October 2008

2422 Alexander Ludwig and Michael Reiter, Sharing Demographic Risk - Who is Afraid of the Baby Bust?, October 2008

2423 Doina Maria Radulescu and Michael Stimmelmayr, The Welfare Loss from Differential Taxation of Sectors in Germany, October 2008

2424 Nikolaus Wolf, Was Germany ever United? Evidence from Intra- and International Trade 1885 - 1933, October 2008

2425 Bruno S. Frey, David A. Savage and Benno Torgler, Noblesse Oblige? Determinants of Survival in a Life and Death Situation, October 2008

2426 Giovanni Facchini, Peri Silva and Gerald Willmann, The Customs Union Issue: Why do we Observe so few of them?, October 2008

2427 Wido Geis, Silke Uebelmesser and Martin Werding, Why go to France or Germany, if you could as well go to the UK or the US? Selective Features of Immigration to four major OECD Countries, October 2008

2428 Geeta Kingdon and Francis Teal, Teacher Unions, Teacher Pay and Student Performance in India: A Pupil Fixed Effects Approach, October 2008

2429 Andreas Haufler and Marco Runkel, Firms' Financial Choices and Thin Capitalization Rules under Corporate Tax Competition, October 2008

2430 Matz Dahlberg, Heléne Lundqvist and Eva Mörk, Intergovernmental Grants and Bureaucratic Power, October 2008

2431 Alfons J. Weichenrieder and Tina Klautke, Taxes and the Efficiency Costs of Capital Distortions, October 2008

2432 Andreas Knabe and Ronnie Schöb, Minimum Wage Incidence: The Case for Germany, October 2008

2433 Kurt R. Brekke and Odd Rune Straume, Pharmaceutical Patents: Incentives for R\&D or Marketing?, October 2008

2434 Scott Alan Carson, Geography, Insolation, and Institutional Change in $19^{\text {th }}$ Century African-American and White Stature in Southern States, October 2008

2435 Emilia Del Bono and Daniela Vuri, Job Mobility and the Gender Wage Gap in Italy, October 2008 